\title{
Synthesis and Characterization of Nanoporous Carbon Carriers for Losartan Potassium Delivery
}

\author{
Aleksander Ejsmont ${ }^{1}\left(\right.$, Anna Stasiłowicz-Krzemień ${ }^{2}\left({ }\right.$, Dominika Ludowicz ${ }^{2}$, Judyta Cielecka-Piontek ${ }^{2, *}(\mathbb{D}$ and \\ Joanna Goscianska ${ }^{1, * \mathbb{D}}$ \\ 1 Faculty of Chemistry, Department of Chemical Technology, Adam Mickiewicz University in Poznań, \\ Uniwersytetu Poznańskiego 8, 61-614 Poznań, Poland; aleksander.ejsmont@amu.edu.pl \\ 2 Faculty of Pharmacy, Department of Pharmacognosy, Poznań University of Medical Sciences, Święcickiego 4, \\ 61-781 Poznań, Poland; astasilowicz@ump.edu.pl (A.S.-K.); dominika.siakowska@interia.eu (D.L.) \\ * Correspondence: jpiontek@ump.edu.pl (J.C.-P.); asiagosc@amu.edu.pl (J.G.)
}

Citation: Ejsmont, A.;

Stasiłowicz-Krzemień, A.; Ludowicz,

D.; Cielecka-Piontek, J.; Goscianska, J.

Synthesis and Characterization of Nanoporous Carbon Carriers for Losartan Potassium Delivery. Materials 2021, 14, 7345. https:// doi.org/10.3390/ma14237345

Academic Editor: Alessandro Pistone

Received: 25 October 2021

Accepted: 26 November 2021

Published: 30 November 2021

Publisher's Note: MDPI stays neutral with regard to jurisdictional claims in published maps and institutional affiliations.

Copyright: (c) 2021 by the authors. Licensee MDPI, Basel, Switzerland. This article is an open access article distributed under the terms and conditions of the Creative Commons Attribution (CC BY) license (https:/ / creativecommons.org/licenses/by/ $4.0 /)$.

\begin{abstract}
Losartan potassium is most commonly used for the treatment of hypertension. In recent years, new applications of this drug have emerged, encouraging the design of novel nanoporous carriers for its adsorption and release. The purpose of this study was to synthesize ordered mesoporous carbon vehicles via a soft-templating method altered with the use of nitrogen precursors and via a hard-templating method followed by chitosan functionalization. As a result, the materials obtained differed in nitrogen content as well as in the number of total surface functional groups. The impact of the modification on the physicochemical properties of carbon carriers and their interaction with losartan potassium during adsorption and release processes was examined. The materials were characterized by various morphologies, specific surface areas (101-1180 $\left.\mathrm{m}^{2} \mathrm{~g}^{-1}\right)$, and the amount of acidic/basic oxygen-containing functional groups (1.26-4.27 mmol g $\left.{ }^{-1}\right)$. These features, along with pore sizes and volumes, had a key effect on the sorption capacity of carbon carriers towards losartan potassium (59-161 $\mathrm{mg} \mathrm{g}^{-1}$ ). Moreover, they contributed to the differential release of the drug (18.56-90.46\%). Losartan potassium adsorption onto the surface of carbonaceous materials was mainly based on the formation of hydrogen bonds and $\pi-\pi$ interactions and followed the Langmuir type isotherm. It has been shown that the choice of the method of carbon carriers' synthesis and their modification allows for the precise control of the kinetics of the losartan potassium release from their surface, resulting in rapid or sustained drug liberation.
\end{abstract}

Keywords: mesoporous carbon vehicles; chitosan; surface modification; nitrogen doping; adsorption of losartan potassium; drug liberation

\section{Introduction}

Aiming for improved pharmacotherapy, scientists progressively try to expand new mechanisms of action of active pharmaceutical ingredients (APIs), which have been known about and applied for many years. One such API example is highly tolerable losartan potassium (LOS), approved by the Food and Drug Administration (FDA) in 1995 and most commonly used for hypertension and renal disease [1]. It is also administered to prevent and control chronic fibrotic diseases such as asthma and myocardial hypertrophy, all during the reduction of platelet aggregation, decreasing the risk of thrombosis and carcinoma [2]. In recent years, it has been discovered that LOS is an angiotensin II antagonist partially capable of protecting lungs against damage caused by coronaviruses, including SARSCoV-2 [3]. Moreover, the intranasal treatment with LOS on rodents revealed its new neuroprotective and memory-improving abilities signifying high potential in Alzheimer's disease prevention $[4,5]$.

The differentiated potential of LOS as a drug prompts the search for novel delivery systems that can contribute to its stabilization and a specific release mode. Up to now, only several vehicles have been proposed for LOS, such as polymer-based floating tablets [6], 
cellulose derivatives $[7,8]$, self-emulsifying systems with lipids, surfactants, and oils $[9,10]$, or patches with microneedles for transdermal delivery [11]. However, the drug carriers must be characterized by biodegradability and biocompatibility, as well as exhibit specific flexibility during preparation, which will allow their parameters to be tailored towards the desired interactions with API. When potential drug-carrier systems are presented, there is often a lack of precision in determining the maximum sorption capacity towards an active substance, as well as the influence of physicochemical properties of carriers on the ability to adsorb and then release the drug. Due to these aspects, ordered mesoporous materials, such as silica and carbons, with well-defined properties can be delivery platforms for the increasingly more complex and biologically active compounds [12,13]. Mesoporous silica is recognized for its biomedical applications [14,15], whereas the carbon materials are usually perceived as common adsorbents rather than drug-delivery systems. For instance, de Andrade et al. [16] applied micro-grain-activated carbon to compare its sorption capacity with organoclay in LOS adsorption processes. Another example is LOS removal presented by Wang and co-workers [17]. They reported a porous carbon for LOS adsorption, followed by oxidative degradation in the presence of potassium peroxymonosulfate. To the best of our knowledge, there are no reports about using porous carbons as LOS delivery platforms. The development of new and upgraded preparation techniques and functionalization methods has led to carbons' more frequent use in drug delivery, particularly ordered mesoporous carbons (OMCs) [18-21].

OMCs are most recognized by their $2-50 \mathrm{~nm}$ pore size range and pore ordering, which they owe to the hard or soft templates participating during carbon syntheses. Mesoporous silica constitutes a solid matrix in the hard-templating method, whilst surfactants are used in the soft-templating approach. In the hard-template method, there are four main steps: the preparation of silica matrix, the impregnation of a matrix with precursors rich in carbon (mostly via wet impregnation or chemical vapor deposition), the carbonization of organic-inorganic (carbon-silica) composite to obtain graphite-like carbon, and the removal of silica by using hydrofluoric acid or alkalis solutions. OMCs obtained in this route are a reversed replica of the matrix with maintained ordering and high specific surface area [22,23]. Moreover, the high stability of carbon after nanocasting provides a good foundation for further carbon functionalization with a low risk of degradation of the ordered structure $[24,25]$. In the soft-template method, polymer surfactants such as triblock copolymers are utilized due to their ability to co-assemble with phenolic resins, which constitute carbon precursors [26,27]. In this route, the main advantage is the convenience of carrying the entire procedure in a single bottle where, under appropriate $\mathrm{pH}$ and temperature conditions, the reactants form a complex polymeric system. Moreover, at this stage, one can introduce carbon sources enriched in heteroatoms, or catalysts facilitating polymerization, as well as other structuring agents, which, reacting with the surfactants, may contribute to a change of the final order of the carbon material. Additionally, after carbonization, there is no need for template removal, as it completely decomposes at high pyrolytic temperatures. Fewer stages of synthesis make it relatively more profitable in terms of time and cost. However, due to the complexity of the reaction system and lack of a rigid template, polymerization may sometimes be disrupted, resulting in lower carbon surface areas obtained by this approach [28].

Depending on the method, type of template, precursors, and conditions of carbonization, the OMCs features such as structure ordering, pores size, particles morphology, and uniformity can be adjusted. As a result, it is possible to obtain porous carbon materials with high hydrothermal stability. Considering them for biomedical applications, OMCs have good biocompatibility and high purity due to the synthetic precursors [29-31]. Nanoporous carbons have unique structures and properties, and they might be used as diagnostic probes, nanocarriers, and biomarkers $[21,32,33]$. In general, nanocarbon materials were reported to have low toxicity and high biocompatibility and be non-pathogenic [34,35]. The toxicity of these materials depends on their unique physical and chemical properties. The most critical parameters are nanoparticle concentration, surface modification, and degree of aggregation 
in vivo. Before being administered as drug carriers, the nanoparticle biocompatibility and toxicity should be assessed. Moreover, there are increasingly more reports confirming their sustained API release, high sorption capacities, simple surface functionalization, and distinctive supramolecular $\pi-\pi$ stacking with aromatic-drug molecules [35,36]. An interesting example of OMCs synthesis and modification specifically for tumor therapy in acidic microenvironments was presented by Huang et al. [37]. They synthesized gated channelinterconnected $\mathrm{OMC}$ doped with $\mathrm{ZnO}$ quantum dots for stimuli-responsive mitoxantrone release. The material was able to release the drug in a controlled manner upon decreasing the $\mathrm{pH}$ of the environment, which matches the acidity of the cancer cells. The surface modification can be also combined with heteroatom doping as in PEG-PEI-modified and nitrogen-doped mesoporous carbon for NIR light-triggered gemcitabine release [38]. The carbon was able to convert light into heat, which melts the polymeric modifier providing the release of the drug. These examples demonstrate the uniqueness and high application potential of porous carbons as carriers for drugs. Therefore, their further development is worthy of consideration.

The aim of our study was to prepare ordered mesoporous carbons using two separate synthetic methods allowing the introduction of nitrogen into one part of the materials, and a significant increase in the presence of oxygen functional groups for the second group of carriers. The main idea was to compare mesoporous carbons obtained by conventional but partially extended or modified methods, which can lead to the same structure ordering of OMCs but different textural parameters and surface chemistry. The compilation of the carbons is intended to show how the relationship with the active substance can be influenced by different carbon synthetic routes and to help in the selection of the right method for the desired adsorption/release effect. To provide such variety, 3-aminophenol (AP) was used to change $\mathrm{N}$-content in carbon structure, whilst chitosan $(\mathrm{CH})$ cationic biopolymer with low- and high molecular weights (MW) was applied to modify carbon surface. Chitosan is widely used in drug-delivery systems because it contributes to increasing API bioavailability and, in some cases, to improving drug retention, biodistribution, and permeability through biological membranes [39]. Subsequently, the OMCs prepared were thoroughly characterized to determine structure ordering, textural parameters, and morphology. Next, carbons with varying nitrogen content and surface-oxygen group functionalities were used as unique carriers for losartan potassium. This was accomplished by the adsorption processes of the drug, which was then released in an environment mimicking gastric fluid. The physicochemical parameters of the obtained materials were correlated with the drug adsorption and release abilities. It was shown that different nitrogen contents, as well as oxygen-containing functional groups, affect the release mode of losartan.

\section{Experimental Section}

\subsection{Synthesis of Ordered Mesoporous Carbons with the Use of 3-Aminophenol}

In order to introduce a low and high amount of nitrogen into carbon materials, the soft-templating method was carried out corresponding to Liu et al. procedure [40]. Firstly, resorcinol (POCH, 99.0\%) and 3-aminophenol (Aldrich, Steinheim, Germany, 98.0\%) in two various molar ratios 0.0636:0.0275 and 0.0275:0.0636, respectively, were dispersed in $540 \mathrm{~mL}$ of distilled water. Further sample denotation is based on the 3-aminophenol (AP) amount used, for lower- $\mathrm{C}_{\mathrm{AP}-\mathrm{L}}(0.0275 \mathrm{~mol})$, for higher- $\mathrm{C}_{\mathrm{AP}-\mathrm{H}}(0.0636 \mathrm{~mol})$. To the vigorously stirred aqueous solution, $0.0499 \mathrm{~mol}$ of hexamethylenetetramine (HMT, Aldrich, 99.0\%), $0.02 \mathrm{~mol}$ of L-arginine (Aldrich, $\geq 98.0 \%$ ), and $22.0 \mathrm{~g}$ of Pluronic F127 (Aldrich) were added. The mixture was mixed at RT for $1 \mathrm{~h}$ until its colour changed to yellow. Then, the bottle was closed and placed in the water bath at $70^{\circ} \mathrm{C}$ for $24 \mathrm{~h}$ with ongoing mixing. The obtained red-brown sediment was centrifuged, washed three times with distilled water, and left at $70{ }^{\circ} \mathrm{C}$ for $12 \mathrm{~h}$. Dried materials were carbonized in argon (flow rate $100 \mathrm{~mL} \mathrm{~min}^{-1}$ ), firstly, at $350{ }^{\circ} \mathrm{C}$ for $2 \mathrm{~h}$, and then at $700{ }^{\circ} \mathrm{C}$ for $3 \mathrm{~h}$. After the process, carbon samples were ground into fine powders. 


\subsection{Synthesis of Chitosan-Functionalized Ordered Mesoporous Carbons}

Chitosan-functionalized ordered mesoporous carbons were obtained in four steps. Firstly, silica template SBA-15 was synthesized. In the bottle containing $19 \mathrm{~mL}$ of $\mathrm{HCl}$ (1.6 mol L ${ }^{-1}$, Avantor Performance Materials Poland S.A.), $0.5 \mathrm{~g}$ of Pluronic P123 (Aldrich) was dissolved at $35^{\circ} \mathrm{C}$. To the acidic solution, $1.1 \mathrm{~mL}$ of TEOS (tetraethyl orthosilicate, $98 \%$ wt., Aldrich) was added in a dropwise manner with continuous stirring while maintaining the previous temperature for $6 \mathrm{~h}$. The mixture was closed in a polypropylene bottle and placed in an oven, at first for $24 \mathrm{~h}$ at $35^{\circ} \mathrm{C}$, then for $6 \mathrm{~h}$ at $100^{\circ} \mathrm{C}$. The resulting precipitate was separated, washed with water, and left for $12 \mathrm{~h}$ at $100{ }^{\circ} \mathrm{C}$. In order to remove the template, dried material was calcined for $8 \mathrm{~h}$ at $550{ }^{\circ} \mathrm{C}$.

Subsequently, a carbon impregnating solution was prepared via dissolving $1.25 \mathrm{~g}$ of sucrose (Aldrich) in $0.14 \mathrm{~mL}$ of $\mathrm{H}_{2} \mathrm{SO}_{4}$ (Avantor Performance Materials) and $5 \mathrm{~mL}$ of water. Then, the silica SBA- 15 template was impregnated twice with as-prepared sucrose solution and heated in two steps-at $100{ }^{\circ} \mathrm{C}$ for $6 \mathrm{~h}$ and at $160^{\circ} \mathrm{C}$ for $6 \mathrm{~h}$. The silica-carbon composites were additionally subjected to the sucrose solution but less concentrated, prepared from $0.8 \mathrm{~g}$ of sucrose, $0.09 \mathrm{~mL}$ of $\mathrm{H}_{2} \mathrm{SO}_{4}$, and $5 \mathrm{~mL}$ of water. The impregnated material was heated in the same as previous manner, at $100{ }^{\circ} \mathrm{C}$ for $6 \mathrm{~h}$ and $160{ }^{\circ} \mathrm{C}$ for $6 \mathrm{~h}$, followed by carbonization at $900^{\circ} \mathrm{C}$ for $3 \mathrm{~h}$ (heating rate $2.5^{\circ} \mathrm{C} \mathrm{min}{ }^{-1}$ ) in an argon atmosphere. To remove the remaining SBA-15 matrix, the material was washed twice with $200 \mathrm{~mL}$ of $5 \%$ HF solution (Avantor Performance Materials), then with water and ethanol. Next, the carbon material was placed in the oven at $100{ }^{\circ} \mathrm{C}$ overnight and labeled as $\mathrm{C}_{\mathrm{SBA}-15}$.

In order to modify $\mathrm{C}_{\mathrm{SBA}-15}$ with chitosan, the sample surface was firstly oxidized with $1 \mathrm{~mol} \mathrm{~L}^{-1}$ of ammonium persulfate solution (APS, Aldrich), and $5 \mathrm{~g}$ of $\mathrm{C}_{\mathrm{SBA}-15}$ and $30 \mathrm{~mL}$ of APS solution were magnetically mixed and heated at $60^{\circ} \mathrm{C}$ for $6 \mathrm{~h}$ under reflux. Then, the material was separated, washed with water, and dried at $100^{\circ} \mathrm{C}$ overnight.

After introducing oxygen functional groups to the carbon surface, chitosan was grafted onto oxidized $\mathrm{C}_{\mathrm{SBA}-15}$. In two different bottles, the solutions of chitosan with low (CH-L) and high $(\mathrm{CH}-\mathrm{H})$ molecular weight were prepared as follows: $0.5 \mathrm{~g}$ of each chitosan was dispersed in $50 \mathrm{~mL}$ of $\mathrm{NaCl}$ solution $\left(0.125 \mathrm{~mol} \mathrm{~L}^{-1}\right)$ and $50 \mathrm{~mL}$ of acetic acid solution $\left(0.1 \mathrm{~mol} \mathrm{~L}^{-1}\right)$. After chitosan dispersion, $2.5 \mathrm{~g}$ of oxidized $\mathrm{C}_{\mathrm{SBA}-15}$ was added to each solution, and mixtures were stirred at RT for $8 \mathrm{~h}$. Afterwards, materials were separated, washed with water, and dried at $100{ }^{\circ} \mathrm{C}$ for $12 \mathrm{~h}$. The obtained chitosan-modified carbon materials were denoted accordingly to the modifier molecular weight $-\mathrm{C}_{\mathrm{CH}-\mathrm{L}}$, and $\mathrm{C}_{\mathrm{CH}-\mathrm{H}}$.

\subsection{Characterization of Materials}

\subsubsection{Powder X-ray Diffraction}

To establish structure ordering of mesoporous carbon carriers, their low-angle XRD profiles were made by D8 Advance Diffractometer (Bruker, $\mathrm{Cu} K \alpha 1$ radiation $\lambda=1.5406 \AA$ ) with step size $0.02^{\circ}$.

\subsubsection{Transmission Electron Microscopy}

To provide an overview of the pore ordering, TEM images were registered. Carbonpowdered samples were embedded on a grid with a perforated carbon film and placed into JEOL 2000 electron microscope operating at $80 \mathrm{kV}$.

\subsubsection{Elemental Analysis}

The CHNS/O element content was measured by using Thermo Scientific FLASH 2000 Elemental Analyzer (OEA).

\subsubsection{Scanning Electron Microscopy}

The morphology of carbon materials was determined by scanning electron microscope (SEM, FEI Helios NanoLab 660). The conditions of the analysis were as follows: room temperature, high-vacuum mode of $7 \times 10^{-4} \mathrm{~Pa}$, and modes were field-free (FF) and high- 
resolution (HR) with $10 \mathrm{kV}$ acceleration voltage and $0.2 \mathrm{nA}$ beam current. The resulting images were registered by secondary electrons using the Everhart-Thornley Detector for FF and Through-Lens Detector for HR.

\subsubsection{Low-Temperature Nitrogen Sorption}

The textural parameters of the synthesized carbon samples were defined by lowtemperature nitrogen adsorption/desorption isotherms, which were obtained after conducting the process at $-196{ }^{\circ} \mathrm{C}$ with the use of a Quantachrome Autosorb IQ apparatus. Before the measurement, in order to remove moisture, materials were degassed for $3 \mathrm{~h}$ at the following temperatures: $\mathrm{C}_{\mathrm{AP}-\mathrm{L}}$ and $\mathrm{C}_{\mathrm{AP}-\mathrm{H}}$ at $200{ }^{\circ} \mathrm{C}, \mathrm{C}_{\mathrm{SBA}-15}$ at $300{ }^{\circ} \mathrm{C}$, and $\mathrm{C}_{\mathrm{CH}-\mathrm{L}}$ and $\mathrm{C}_{\mathrm{CH}-\mathrm{H}}$ at $100{ }^{\circ} \mathrm{C}$, to avoid the decomposition of chitosan. The specific surface area was ascertained via calculations using Brunauer-Emmett-Teller (BET) method, while the average pore size was evaluated using Barret-Joyner-Halenda (BJH) method.

\subsubsection{Surface Oxygen Functional Groups}

The Boehm titration method was applied to establish the amount of acidic and basic oxygen functional groups on the surface of carbon materials. Carbon samples required preparation before titration as follows: $0.1 \mathrm{~g}$ of carbon was immersed in $10 \mathrm{~mL}$ of $\mathrm{NaOH}$ solution $\left(0.1 \mathrm{~mol} \mathrm{~L}^{-1}, \mathrm{POCH}\right)$ to neutralize acidic groups. The mixture was agitated for $24 \mathrm{~h}$ at RT, then the material was separated and the solution was titrated with $\mathrm{HCl}$ solution (0.1 mol L ${ }^{-1}$, Chempur) to determine acidic groups amount. In turn, to calculate basic functional groups amount, the same amount of carbon was dispersed in $\mathrm{HCl}$ solution $\left(0.1 \mathrm{~mol} \mathrm{~L}^{-1}\right)$. Then, the mixture was agitated and separated similarly as previously, followed by titration with $\mathrm{NaOH}$ solution $\left(0.1 \mathrm{~mol} \mathrm{~L}^{-1}\right)$. All titration procedures were conducted in the presence of methyl orange as an indicator.

\subsubsection{Infrared Spectroscopy}

Fourier-transform infrared spectra (FT-IR) were registered by using FT-IR Bruker IFS 66v/S 161 spectrometer. The carbon samples and carbon-losartan systems (ca. $0.3 \mathrm{mg}$ ) were grounded with anhydrous $\mathrm{KBr}$ (ca. $0.25 \mathrm{mg}$ ), followed by tablets formation. The analysis was conducted in a wavenumber range of $4000-400 \mathrm{~cm}^{-1}$ (resolution of $0.5 \mathrm{~cm}^{-1}$; the number of scans: 64).

\subsection{Losartan Potassium Adsorption Studies}

The obtained carbon materials were applied as vehicles for losartan potassium, therefore adsorption abilities of materials towards drug have been measured via Agilent Cary $60 \mathrm{UV}$-Vis spectrophotometer at a wavelength of $233 \mathrm{~nm}$. The specific amount of each material $(25 \mathrm{mg})$ was dispersed in losartan solutions of concentration range 5-100 $\mathrm{mg} \mathrm{L}^{-1}$ and agitated at RT for $24 \mathrm{~h}$. Subsequently, carbon carriers with adsorbed losartan were separated, and the absorbance of the remaining solutions was measured, followed by calculations of sorption capacity using the formula below.

$$
q_{e}=\frac{\left(C_{0}-C_{e}\right) \cdot V}{m}
$$

$q_{e}$ - the amount of adsorbed losartan onto nanoporous carbon carriers $\left(\mathrm{mg} \mathrm{g}^{-1}\right)$,

$\mathrm{C}_{0}$ - the initial concentration of losartan $\left(\mathrm{mg} \mathrm{L}^{-1}\right)$,

$\mathrm{C}_{e}$ - the equilibrium concentration of losartan after adsorption $\left(\mathrm{mg} \mathrm{L}^{-1}\right)$,

$V$-the volume of losartan solution (L),

$m$-the mass of carbon adsorbent (g).

The obtained adsorption results were analyzed and fitted to two types of adsorption isotherms of the Langmuir and Freundlich [41,42]. By referring to the correlation coefficients $\left(R^{2}\right)$ of the models, the mechanism of adsorption has been established. 
The Langmuir isotherm is described by the following equation:

$$
\frac{C_{e}}{q_{e}}=\frac{1}{q_{m} K_{L}}+\frac{C_{e}}{q_{m}}
$$

$q_{m}$-the maximum monolayer adsorption capacity of carbon adsorbent $\left(\mathrm{mg} \mathrm{g}^{-1}\right)$,

$K_{L}$-the Langmuir constant denoted the energy of adsorption and affinity of binding sites $\left(\mathrm{L} \mathrm{mg}^{-1}\right)$.

The Freundlich isotherm and its linear form are described by the Equation (3):

$$
\ln q_{e}=\ln K_{f}+\frac{1}{n} \ln C_{e}
$$

$K_{F}-$ Freundlich constant, which relates to the adsorption capacity of the adsorbent $\left(\mathrm{mg} \mathrm{g}^{-1}\right.$ $\left.\left(\mathrm{L} \mathrm{mg}^{-1}\right)^{1 / \mathrm{n}}\right)$,

$n$-constant, which indicates how favorable is the adsorption process.

\subsection{Losartan Release Studies}

The release rates of losartan potassium from carbon carriers were tested in a paddle apparatus (Agilent 708-DS; Agilent, Santa Clara, CA, USA) with a rotation speed of $50 \mathrm{rpm}$. The carrier-API systems were weighted to gelatin capsules and placed into springs acting as sinkers preventing flotation in the vessel. The test was conducted in the $\mathrm{HCl}$ solution $\left(0.1 \mathrm{~mol} \mathrm{~L}^{-1}\right)$, according to FDA recommendations. The temperature of the medium was $37^{\circ} \mathrm{C} \pm 0.5^{\circ} \mathrm{C}$. During the study, at specified time points, $5 \mathrm{~mL}$ of samples was collected halfway between the surface of the medium and the paddle top edge, no closer than 1 $\mathrm{cm}$ from the wall of the vessel, and refilled by a clean medium of the temperature of $37^{\circ} \mathrm{C} \pm 0.5^{\circ} \mathrm{C}$. The vessels were covered during the test, and the study medium temperature was maintained. The analysis of the samples was performed by the HPLC method (Shimadzu, Tokyo, Japan) at a wavelength of $233 \mathrm{~nm}$. The column (Phenomenex $250 \mathrm{~mm}$ $\times 4.6 \mathrm{~mm} ; 5 \mu \mathrm{m}$; Torrance, CA, USA) oven was set at $30^{\circ} \mathrm{C}$; the stationary phase was $0.1 \%$ formic acid and acetonitrile (40:60) at the flow of $0.8 \mathrm{~mL} \mathrm{~min}^{-1}$.

To establish the type of losartan liberation, datasets were correlated to five mathematical models: zero-order (\% LOS release vs. time) (4), first-order (log of \% LOS release vs. time) (5), Higuchi's model (\% LOS release vs. square root of time) (6), Hixson-Crowell (cube root of \% LOS remaining vs. time) (7), and Korsmeyer-Peppas model (log of \% LOS vs. log time) (8) [43]. The criterion of fitting was the correlation coefficient $\left(\mathrm{R}^{2}\right)$, whose highest value indicated the most probable release mechanism.

$$
\begin{gathered}
F_{t}=k_{0} t_{e} \\
F_{t}=1-e^{-k t} \\
F_{t}=k_{H} \sqrt{t} \\
\sqrt[3]{F_{0}}-\sqrt[3]{F_{t}}=k_{H C} t \\
F_{t}=k t^{n}
\end{gathered}
$$

$F_{t}$-the fraction of losartan released in time,

$F_{0}$ - the initial amount of losartan in the nanocarrier,

$k_{0}, k_{t}, k_{H}, k_{H C}, k$-the release constants of particular kinetic models, $n$-the diffusion exponent.

\subsection{Permeability Study}

Gastrointestinal (GIT) permeability was performed using PAMPA (parallel artificial membrane permeability assay) based on passive diffusion. The samples were dissolved in DMSO, mixed with donor solution ( $\mathrm{pH}$ 1.2), then they were added to donor compartments 
on a 96-well plate. The system consists also of another 96-well plate with acceptor chambers. Donor and acceptor compartments are separated by a $120 \mu \mathrm{m}$ thick microfilter disc coated with a $20 \%(w / v)$ dodecane solution of a lecithin mixture (Pion, Inc., Billerica, MA, USA). Both plates were combined as one and incubated for $3 \mathrm{~h}$ at the temperature of $37^{\circ} \mathrm{C}$ in a humidity-saturated atmosphere. After the time of incubation, the compartments were split and their content was analyzed using the HPLC method (see Section 2.5). The apparent permeability coefficient (Papp) was calculated using the following equation:

$$
\begin{gathered}
P_{\text {app }}=\frac{-\ln \left(1-\frac{C_{A}}{C_{\text {equilibrium }}}\right)}{S \times\left(\frac{1}{V_{D}}+\frac{1}{V_{A}}\right) \times t} \\
C_{\text {equilibrium }}=\frac{C_{D} \times V_{D}+C_{A} \times V_{A}}{V_{D}+V_{A}}
\end{gathered}
$$

where:

$V_{D}$-donor volume,

$V_{A}$-acceptor volume,

$C_{\text {equilibrium }}$-equilibrium concentration,

$S$-membrane area,

$t$-incubation time (in seconds).

\section{Results and Discussion}

\subsection{Physicochemical Characterization of Nanoporous Carbon Carriers}

The divergent synthetic routes for carbon carrier preparation, i.e., soft-templating method with the use of 3-aminophenol (AP) and nanocasting followed by chitosan $(\mathrm{CH})$ grafting, were utilized to generate nitrogen and oxygen-containing functional groups in their structures (Figure 1). Nitrogen-enriched mesoporous carbons with low $\left(\mathrm{C}_{\mathrm{AP}-\mathrm{L}}\right)$ and high $\left(\mathrm{C}_{\mathrm{AP}-\mathrm{H}}\right)$ amounts of $\mathrm{AP}$ were compared to the carbons functionalized with low $\left(\mathrm{C}_{\mathrm{CH}-\mathrm{L}}\right)$ and high $\left(\mathrm{C}_{\mathrm{CH}-\mathrm{H}}\right)$ molecular weight chitosan. The motivation for such modifications of mesoporous carbons was to establish how the functional groups will interact with losartan potassium and the assessment of their application potential as carriers in the processes of drug adsorption and release.

The carbon materials obtained via two different approaches revealed ordered structures as evidenced by the peaks visible in the small-angle XRD profiles (Figure 2). The characteristic sharp peak at $2 \theta=1^{\circ}$ observed for all samples corresponds to the (211) plane and suggests the presence of hexagonal pore arrays. The differences in the intensity of this peak are especially noticeable for the $\mathrm{C}_{\mathrm{AP}-\mathrm{L}}$ and $\mathrm{C}_{\mathrm{AP}-\mathrm{H}}$ materials. In the case of the first sample, the reflection is more pronounced. It can be concluded that using a lower amount of AP provides better mesoporous structure ordering. Moreover, other peaks in the range between 1.5 and $2.0^{\circ}$ are also sharper in the $X R D$ profile of the $C_{A P-L}$ sample. The diffractograms of carbon materials based on $\mathrm{C}_{\mathrm{SBA}-15}$ contain less intensive reflections in the analyzed range, which indicate less ordered hexagonal structure affiliated to the p6mm space group. It was established that the use of chitosan for functionalization of $\mathrm{C}_{\mathrm{SBA}-15}$ does not significantly affect the ordering of the mesoporous structure. Only in the case of $\mathrm{C}_{\mathrm{CH}-\mathrm{L}}$ material, a slight reduction in peaks intensity is noticed. It implies that smaller chitosan molecules could attach not only to the carbon surface but also could be partially loaded into the mesopores [44].

The arrangement of the pore structure was further confirmed by TEM images of OMCs (Figure 3). Referring to the XRD results, all materials showed a hexagonal ordering, which corresponds to the earlier reports $[45,46]$. This is particularly evident for the carbons obtained by the soft-templating method, which are shown in Figure 3A,B. The images present a detailed cross-section of the porous network, from which it is clear that the pores are hexagonally arranged resembling a honeycomb structure. TEM images of carbons obtained by the hard-template method are displayed in Figure 3C-E. They demonstrate 
the individual pore channels with a high degree of order. Interestingly, pristine carbon, as well as functionalized materials, are characterized by the same pore ordering. Thus, there is a lack of the negative effect of chitosan modification on material structures proving their stability.

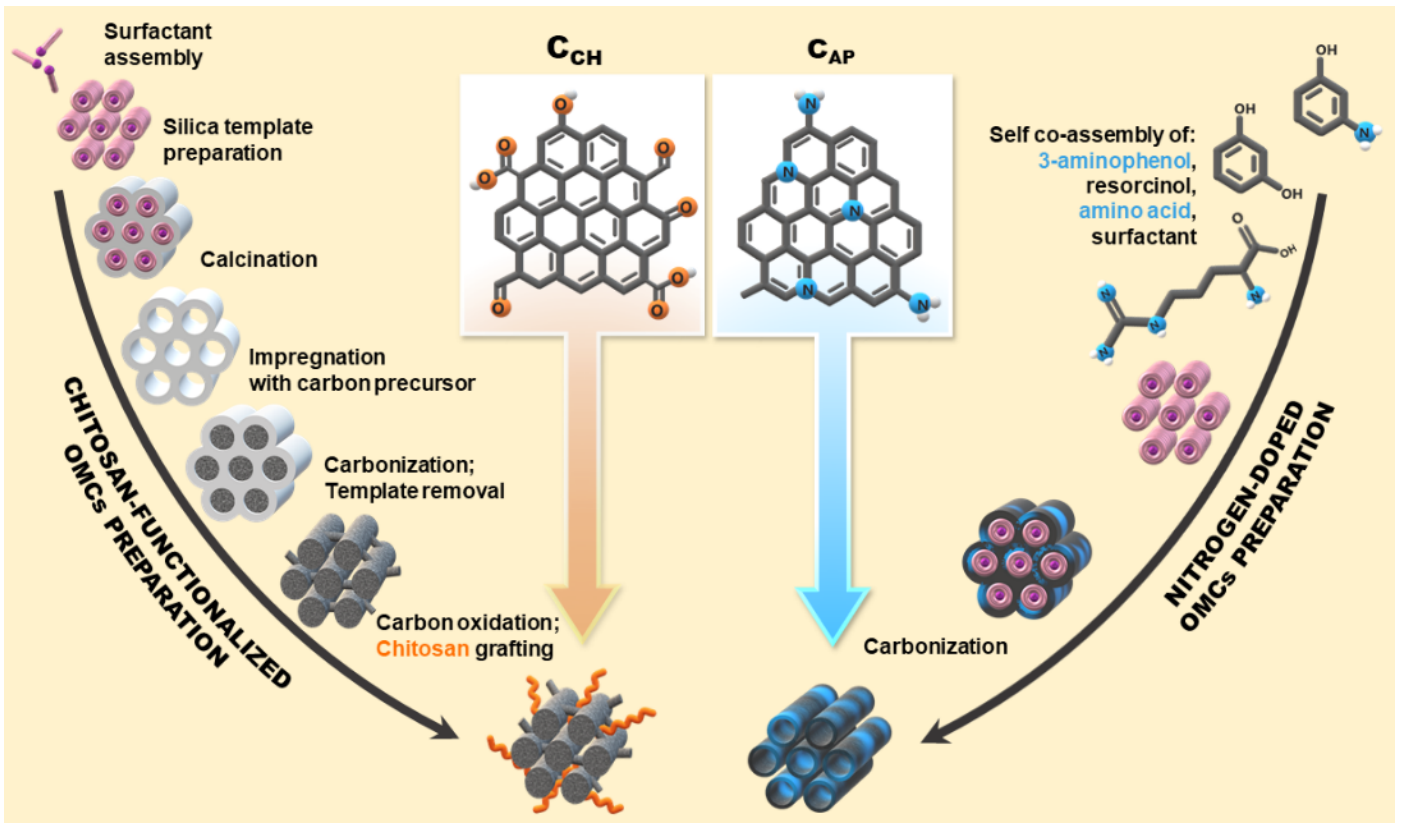

Figure 1. Scheme representing syntheses of carbon carriers via different routes. On the left: chitosan-modified ordered mesoporous carbons $\left(\mathrm{C}_{\mathrm{CH}}\right)$ via the hard-templating method, followed by oxidation and chitosan grafting. On the right: nitrogen-doped ordered mesoporous carbons $\left(\mathrm{C}_{\mathrm{AP}}\right)$ through soft-templating method with 3-aminophenol and amino acid (L-arginine) as N-dopants.

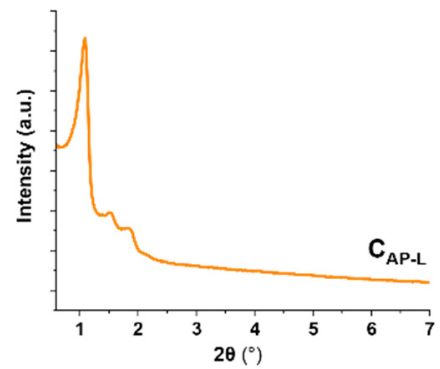

(A)

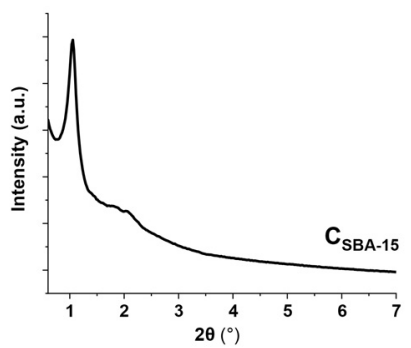

(C)

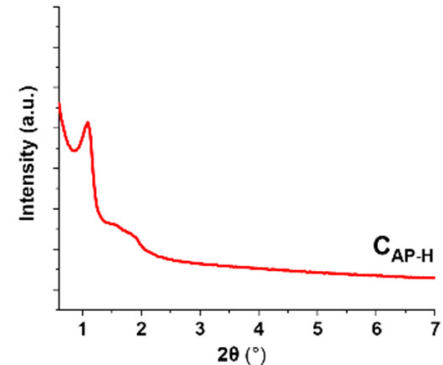

(B)

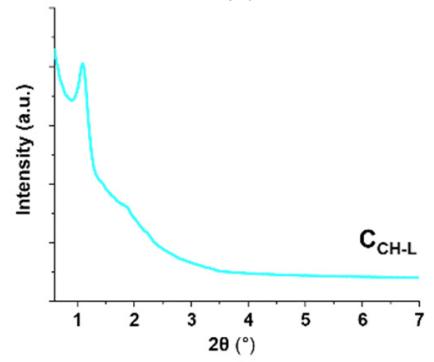

(D)

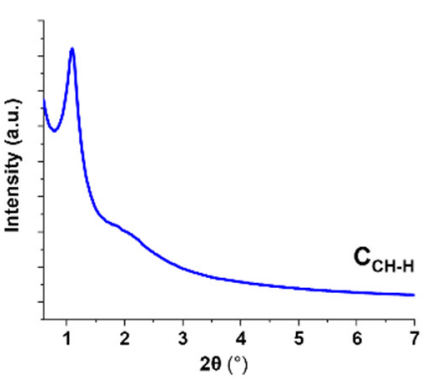

(E)

Figure 2. XRD profiles in the small-angle range of the carbon materials: $\mathrm{C}_{\mathrm{AP}-\mathrm{L}}(\mathbf{A}), \mathrm{C}_{\mathrm{AP}-\mathrm{H}}(\mathbf{B}), \mathrm{C}_{\mathrm{SBA}-15}(\mathbf{C}), \mathrm{C}_{\mathrm{CH}-\mathrm{L}}(\mathbf{D})$, and $\mathrm{C}_{\mathrm{CH}-\mathrm{H}}(\mathbf{E})$. 


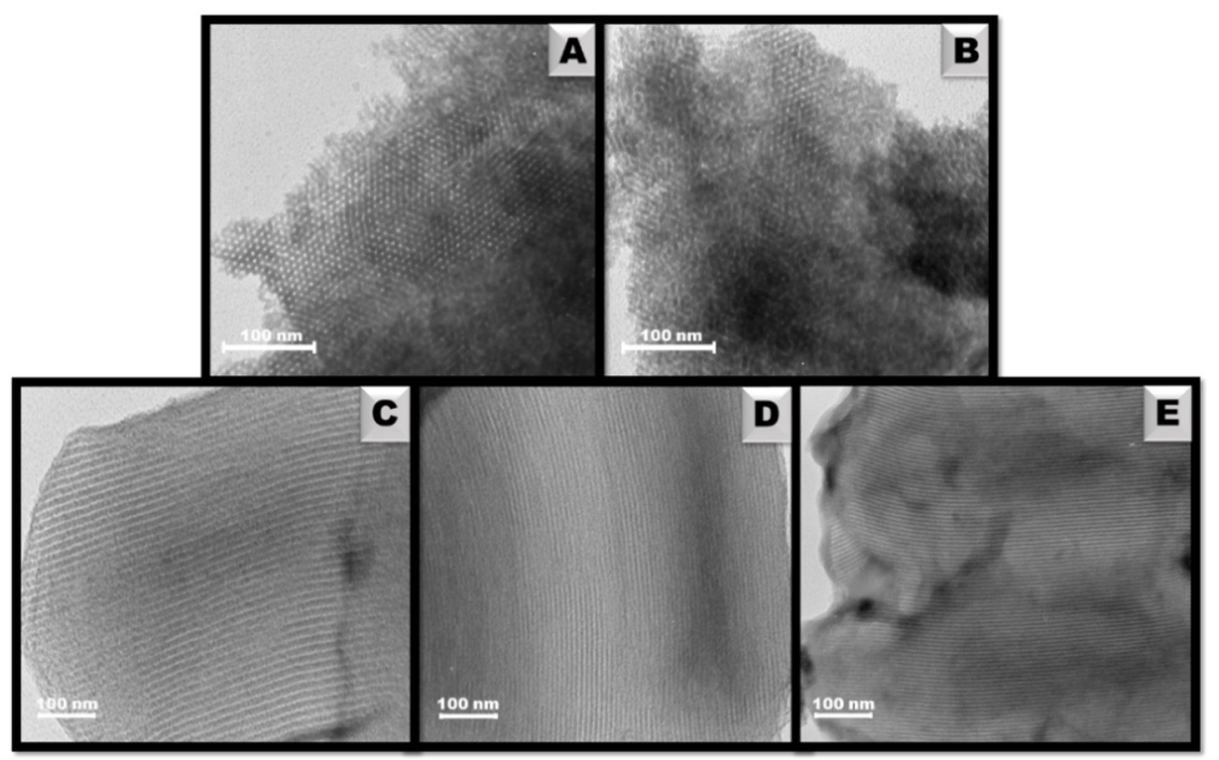

Figure 3. TEM images of ordered mesoporous carbons: $\mathrm{C}_{\mathrm{AP}-\mathrm{L}}(\mathrm{A}), \mathrm{C}_{\mathrm{AP}-\mathrm{H}}(\mathbf{B})$ cross-section revealing hexagonal honeycomb order; $\mathrm{C}_{\mathrm{SBA}-15}(\mathbf{C}), \mathrm{C}_{\mathrm{CH}-\mathrm{L}}(\mathbf{D})$, and $\mathrm{C}_{\mathrm{CH}-\mathrm{H}}(\mathbf{E})$ side view showing independent cylindrical channels.

The analysis of elemental composition confirmed successful enriching of carbon materials with heteroatoms, i.e., nitrogen in the case of $\mathrm{C}_{\mathrm{AP}-\mathrm{L}}$ and $\mathrm{C}_{\mathrm{AP}-\mathrm{H}}$ and oxygen for $\mathrm{C}_{\mathrm{CH}-\mathrm{L}}$ and $\mathrm{C}_{\mathrm{CH}-\mathrm{H}}$ (Table 1). Using AP, HMT, and L-arginine during the carbon synthesis led to the introduction of $3.10 \mathrm{wt} . \%$ and $6.42 \mathrm{wt} . \%$ of nitrogen for $\mathrm{C}_{\mathrm{AP}-\mathrm{L}}$ and $\mathrm{C}_{\mathrm{AP}-\mathrm{H}}$, respectively. The higher amount of aminophenol added to the synthetic mixture increased percentage content of nitrogen in carbon structure, which signifies that this method can be further adjusted for the desired N-doping. The carbon materials obtained by the soft template method $\left(\mathrm{C}_{\mathrm{AP}-\mathrm{L}}, \mathrm{C}_{\mathrm{AP}-\mathrm{H}}\right)$ exhibit a more carbon-rich structure (ca. $>86 \mathrm{wt} \%$ ) compared to samples synthesized via hard-templating approach $\left(\mathrm{C}_{\mathrm{SBA}-15}, \mathrm{C}_{\mathrm{CH}-\mathrm{L}}, \mathrm{C}_{\mathrm{CH}-\mathrm{H}}\right)$. This is due to the fact that aminophenol, besides doping samples with nitrogen, also constitutes a source of carbon together with resorcinol. Nano-casted carbons contain about 69-82 wt.\% of carbon but significantly more oxygen. $\mathrm{C}_{\mathrm{SBA}-15}$ exhibits $14.84 \mathrm{wt}$.\% of oxygen in the structure, whilst $\mathrm{CH}$-modified materials display $14 \mathrm{wt} . \%$ more. The oxygen quantity is 28.83 and 29.02 wt.\% for $\mathrm{C}_{\mathrm{CH}-\mathrm{L}}$ and $\mathrm{C}_{\mathrm{CH}-\mathrm{H}}$ samples, respectively. Chitosan is a polymer rich in oxygen functionalities; therefore, it increased the amount of oxygen in the carbon structure. However, it should be highlighted that before modification of $\mathrm{C}_{\mathrm{SBA}-15}$ with chitosan, carbon material was oxidized to generate oxygen moieties. They facilitated further modification with polymer but also partially increased oxygen content [18].

Table 1. The elemental composition of carbon carriers.

\begin{tabular}{ccccc}
\hline Material & N (wt.\%) & C (wt.\%) & H (wt.\%) & O (wt.\%) \\
\hline C $_{\text {AP-L }}$ & 3.10 & 90.15 & 1.11 & 6.89 \\
C $_{\text {AP-H }}$ & 6.42 & 86.31 & 1.55 & 5.72 \\
C $_{\text {SBA-15 }}$ & 0.48 & 82.32 & 2.36 & 14.84 \\
C $_{\text {CH-L }}$ & 0.30 & 69.46 & 1.41 & 28.83 \\
C $_{\text {CH-H }}$ & 0.26 & 69.18 & 1.54 & 29.02 \\
\hline
\end{tabular}

The topography of the surface and shape of carbon particles were investigated by scanning electron microscopy and SEM images are depicted in Figure 4. Among all materials, $\mathrm{C}_{\mathrm{AP}-\mathrm{L}}$ is characterized by the most unique polyhedron-like particles. Notably, it is possible to separate single particles from others and estimate their size, which is $\sim 5 \mu \mathrm{m}$ (Figure 4A). Such morphology corresponds to the most pronounced XRD peaks for the 
maintained p6mm mesostructure of $\mathrm{C}_{\mathrm{AP}-\mathrm{L}}$. Using a higher amount of aminophenol during carbon synthesis led to the loss of the uniform polyhedrons, and wavy heterogeneous folds were formed in $\mathrm{C}_{\mathrm{AP}-\mathrm{H}}$ (Figure $4 \mathrm{~B}$ ). Li et al. [40] reported that a high amount of 3-aminophenol may cause a partial degradation of carbon structural ordering, thus it disrupts the creation of uniform particles. The materials synthesized by the hard template method utilizing SBA-15 as a template (Figure 4C-E) are very similar to each other, and the worm-like particles of carbons resemble the shape of the applied silica [47]. Elongated particles of sizes 1-3 $\mu \mathrm{m}$ also appear in functionalized samples $\mathrm{C}_{\mathrm{CH}-\mathrm{L}}$ and $\mathrm{C}_{\mathrm{CH}-\mathrm{H}}$. Hence, it can be concluded that neither oxidation nor modification with chitosan affected the morphology of the carbon material.

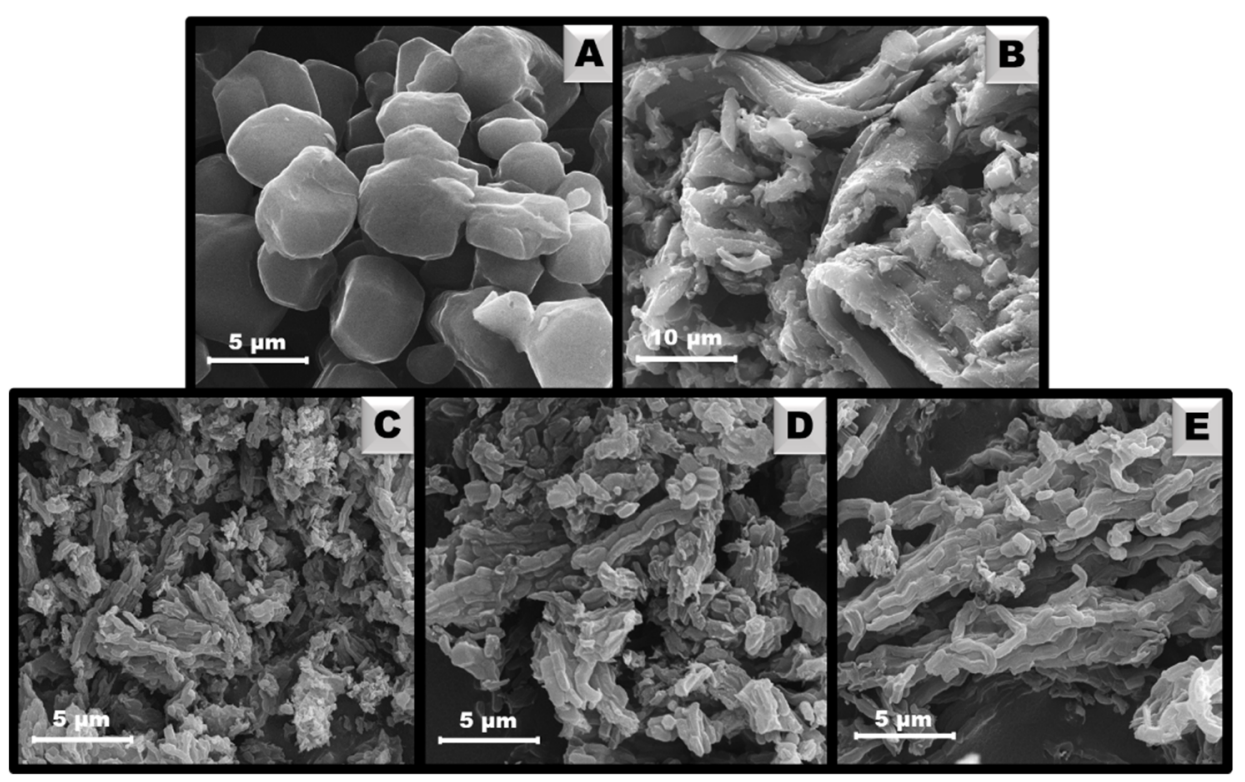

Figure 4. SEM images of ordered mesoporous carbons: $\mathrm{C}_{\mathrm{AP}-\mathrm{L}}(\mathbf{A}), \mathrm{C}_{\mathrm{AP}-\mathrm{H}}(\mathbf{B}), \mathrm{C}_{\mathrm{SBA}-15}(\mathbf{C}), \mathrm{C}_{\mathrm{CH}-\mathrm{L}}(\mathbf{D})$, and $\mathrm{C}_{\mathrm{CH}-\mathrm{H}}(\mathbf{E})$.

The textural parameters of carbon samples are listed in Table 2. They were established via proper calculations based on low-temperature adsorption/desorption of nitrogen. The carbon materials prepared by the soft-templating method have the smallest surface area: $C_{A P-L}-107 \mathrm{~m}^{2} \mathrm{~g}^{-1}$ and $\mathrm{C}_{\mathrm{AP}-\mathrm{H}}-101 \mathrm{~m}^{2} \mathrm{~g}^{-1}$. The reason for such values is possible disruption occurrence, during micelle assembly and polymerization, caused by adding nitrogen-rich reagents to synthetic mixture. $\mathrm{C}_{\mathrm{AP}-\mathrm{L}}$ stands out from other materials with the highest pore diameter of $9.22 \mathrm{~nm}$, which has lowered almost 5-fold for $\mathrm{C}_{\mathrm{AP}-\mathrm{H}}$ resulting in $1.67 \mathrm{~nm}$. In contrast, $C_{\mathrm{SBA}-15}$ revealed the most developed surface area of $1180 \mathrm{~m}^{2} \mathrm{~g}^{-1}$ decreasing after modification with chitosan to $547 \mathrm{~m}^{2} \mathrm{~g}^{-1}$ and $483 \mathrm{~m}^{2} \mathrm{~g}^{-1}$ for $\mathrm{C}_{\mathrm{CH}-\mathrm{L}}$ and $\mathrm{C}_{\mathrm{CH}-\mathrm{H}}$, respectively. Firstly, carbon surface oxidation and newly generated functional groups led to a surface area reduction. It is also visible by the lowered pore volumes and diameters from $1.17 \mathrm{~cm}^{3} \mathrm{~g}^{-1}$ and $4.23 \mathrm{~nm}$ for pristine carbon, to $0.47 / 0.42 \mathrm{~cm}^{3} \mathrm{~g}^{-1}$ and 3.42/3.29 nm for the modified samples. Additionally, attaching the chitosan onto the carbon surface could partially block access to the pores. Lastly, the reduced surface area of the modified carbons can be also explained by the lack of porosity in the polymer itself. 
Table 2. Textural parameters of $\mathrm{C}_{\mathrm{AP}-\mathrm{L}}, \mathrm{C}_{\mathrm{AP}-\mathrm{H}}, \mathrm{C}_{\mathrm{SBA}-15}, \mathrm{C}_{\mathrm{CH}-\mathrm{L}}$, and $\mathrm{C}_{\mathrm{CH}-\mathrm{H}}$.

\begin{tabular}{|c|c|c|c|}
\hline Material & $\begin{array}{l}\text { Specific Surface Area } \\
\qquad\left(\mathrm{m}^{2} \mathrm{~g}^{-1}\right)\end{array}$ & $\begin{array}{l}\text { Total Pore Volume } \\
\qquad\left(\mathrm{cm}^{3} \mathrm{~g}^{-1}\right)\end{array}$ & $\begin{array}{l}\text { Average Pore Diameter } \\
\text { (nm) }\end{array}$ \\
\hline $\mathrm{C}_{\mathrm{AP}-\mathrm{L}}$ & 107 & 0.25 & 9.22 \\
\hline $\mathrm{C}_{\mathrm{AP}-\mathrm{H}}$ & 101 & 0.04 & 1.67 \\
\hline $\mathrm{C}_{\text {SBA-15 }}$ & 1180 & 1.17 & 4.23 \\
\hline $\mathrm{C}_{\mathrm{CH}-\mathrm{L}}$ & 547 & 0.47 & 3.42 \\
\hline $\mathrm{C}_{\mathrm{CH}-\mathrm{H}}$ & 483 & 0.42 & 3.29 \\
\hline
\end{tabular}

Before analyzing the adsorption/release abilities of nanoporous carbon carriers, their surface chemistry has to be determined. Oxygen-containing functional groups have a major influence on both sorption capacities towards drug and the manner of its liberation from the delivery platform. The amount of acidic and basic moieties present on the surface of mesoporous carbons established via the Boehm method is displayed in Figure 5 [48]. All materials revealed different contents of oxygen-containing functional groups. Chitosan-functionalized carbons exhibit the richest surface chemistry (total number of groups over $4 \mathrm{mmol} \mathrm{g}^{-1}$ ), whilst $\mathrm{N}$-doped materials have the largest number of basic groups. Interestingly, $\mathrm{C}_{\mathrm{AP}-\mathrm{L}}$ has more basic functional groups $\left(1.99 \mathrm{mmol} \mathrm{g}^{-1}\right)$ than $\mathrm{C}_{\mathrm{AP}-\mathrm{H}}$ $\left(1.50 \mathrm{mmol} \mathrm{g}^{-1}\right)$. Nitrogen introduction could lead to the generation of amide groups, while increased basicity is also influenced by groups such as quinones, chromenes, and pyrenes $[49,50]$. Thus, there is no dependence that higher quantities of nitrogen cause higher basicity of carbon surface. The use of the smaller amount of aminophenol and more resorcinol in the synthesis of $\mathrm{C}_{\mathrm{AP}-\mathrm{L}}$ ultimately resulted in the total number of acidic and basic groups of $3.48 \mathrm{mmol} \mathrm{g}^{-1}$, where for $\mathrm{C}_{\mathrm{AP}-\mathrm{H}}$ it is $2.23 \mathrm{mmol} \mathrm{g}^{-1}$. The surface of nonmodified $\mathrm{C}_{\mathrm{SBA}-15}$ shows acidic nature. The number of oxygen functional groups was found to be $1.24 \mathrm{mmol} \mathrm{g}^{-1}$. The oxidation process and subsequent modification of the $\mathrm{C}_{\text {SBA-15 }}$ surface with chitosan resulted in a significant increase in the total number of functional groups, with a predominance of acidic ones. Both chitosan-modified carbons, $\mathrm{C}_{\mathrm{CH}-\mathrm{L}}$ and $\mathrm{C}_{\mathrm{CH}-\mathrm{H}}$, have a comparable number of acidic groups, $3.68 \mathrm{mmol} \mathrm{g}^{-1}$ and $3.72 \mathrm{mmol} \mathrm{g}^{-1}$, respectively. It suggests that the molecular weight of chitosan has little impact on the number of oxygen moieties.

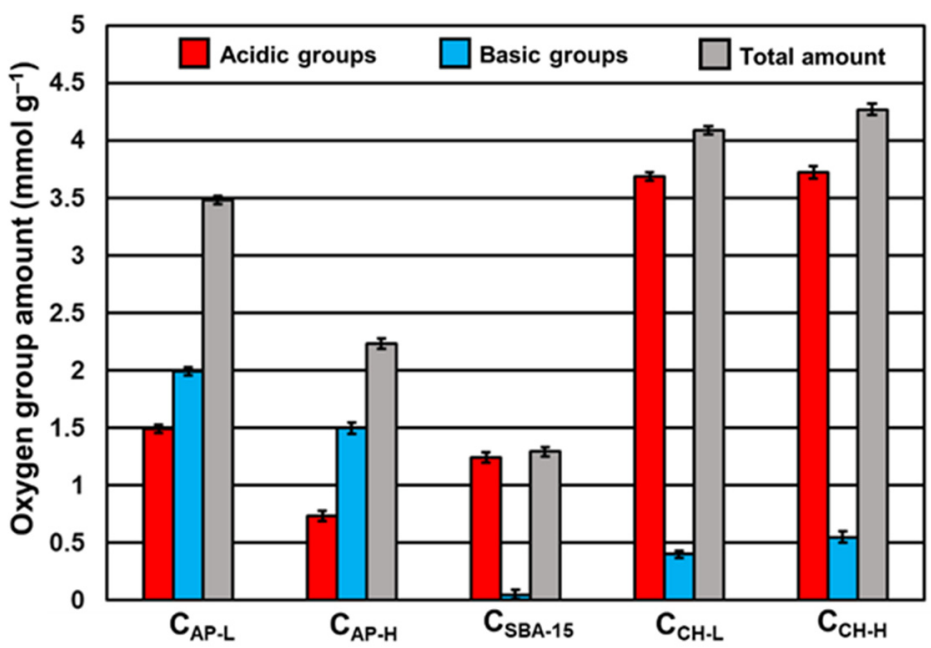

Figure 5. Amount of acidic and basic oxygen functional groups on the carbon carriers' surface determined via Boehm method.

\subsection{Adsorption and Release of Losartan Potassium}

Nanoporous carbon materials were used as delivery platforms for losartan potassium. To establish how losartan binds to the carriers, the FT-IR spectra of each carbon material and carrier-drug systems are demonstrated in Figure 6 and further analyzed. In the FT-IR 
spectrum of losartan potassium, a band at $671 \mathrm{~cm}^{-1}$ characteristic for -OH out-of-plane bending vibrations is visible (Figure 6A) [51]. The band at $761 \mathrm{~cm}^{-1}$ can be associated with stretching vibrations of $\mathrm{C}-\mathrm{Cl}$. At the wavenumber of $788 \mathrm{~cm}^{-1}$, the band assigned to aromatic $\mathrm{C}-\mathrm{H}$ out-of-plane bending vibrations is identified. $\mathrm{C}-\mathrm{O}$ stretching vibrations and breathing of aromatic rings were recorded in the region 997 to $1074 \mathrm{~cm}^{-1}$. Due to the wagging vibrations of $\mathrm{C}-\mathrm{H}$ in the aliphatic chain and stretching vibrations of $\mathrm{C}-\mathrm{N}$, a band at $1257 \mathrm{~cm}^{-1}$ appeared in the FT-IR spectrum. In addition, the absorption bands at $1423 \mathrm{~cm}^{-1}$ and $1458 \mathrm{~cm}^{-1}$ are related to methyl $\mathrm{C}-\mathrm{H}$ symmetric bending vibrations and $-\mathrm{CH}_{2}-$ and $\mathrm{C}-\mathrm{H}$ bending vibrations in the aromatic rings. The band at the wavenumber of $1579 \mathrm{~cm}^{-1}$ is ascribed to $\mathrm{N}=\mathrm{N}$ and $\mathrm{C}=\mathrm{C}$ stretching vibrations. The bands at $2870 \mathrm{~cm}^{-1}$ and $2931 \mathrm{~cm}^{-1}$ prove the presence of symmetric stretching vibrations of $-\mathrm{CH}_{2}-$. In turn, the band at $2958 \mathrm{~cm}^{-1}$ is associated with asymmetric $-\mathrm{CH}_{3}$ vibrations.

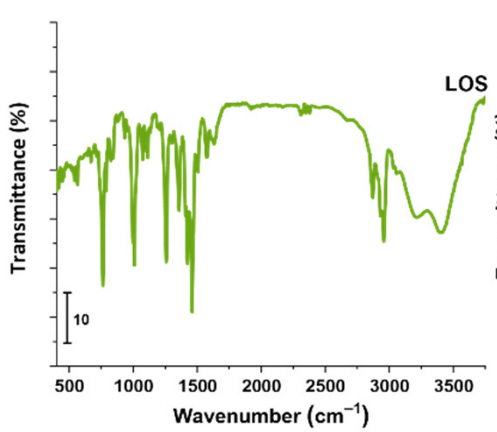

(A)

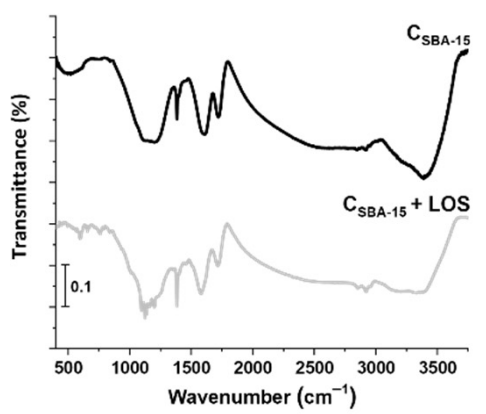

(D)

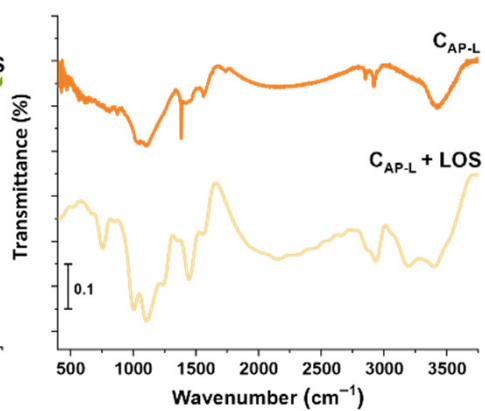

(B)

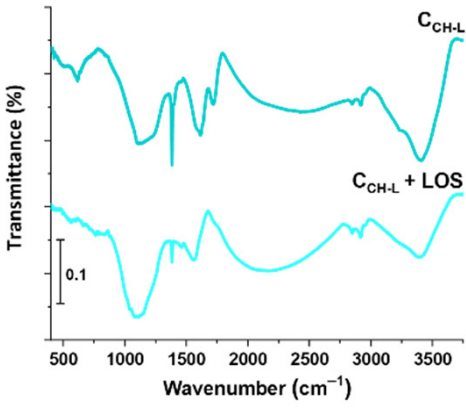

(E)

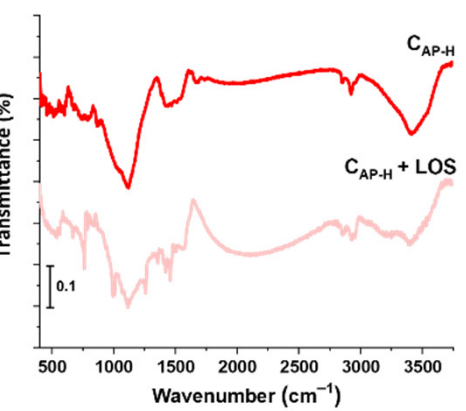

(C)

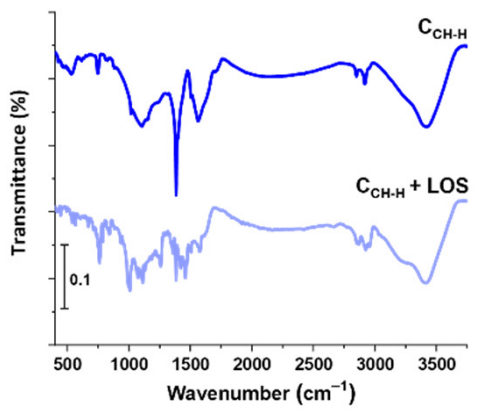

(F)

Figure 6. FT-IR spectra of losartan potassium (A), pure carbon materials and carrier-API systems: $\mathrm{C}_{\mathrm{AP}-\mathrm{L}}(\mathbf{B}), \mathrm{C}_{\mathrm{AP}-\mathrm{H}}(\mathbf{C})$, $\mathrm{C}_{\mathrm{SBA}-15}(\mathbf{D}), \mathrm{C}_{\mathrm{CH}-\mathrm{L}}(\mathbf{E})$, and $\mathrm{C}_{\mathrm{CH}-\mathrm{H}}(\mathbf{F})$.

The FT-IR spectra of all mesoporous carbon materials contain wide bands at $\sim 3400 \mathrm{~cm}^{-1}$ appearing from several phenomena: the $\mathrm{O}-\mathrm{H}$ stretching vibrations of the adsorbed water, the vibrations of $-\mathrm{COOH}$, and the intramolecular hydrogen bonds [52,53]. Moreover, every sample after losartan adsorption indicates in this region a new band at $3250 \mathrm{~cm}^{-1}$ coming from the new $\mathrm{N}-\mathrm{H}$ bond, which is one of the confirmations of the presence of the drug on the carbon surfaces. The repeating in all cases bands at $\sim 2850 \mathrm{~cm}^{-1}$ and $\sim 2920 \mathrm{~cm}^{-1}$ correspond to aliphatic $-\mathrm{CH}_{3}$ and/or $-\mathrm{CH}_{2}-$ groups. By analyzing FT-IR spectra of the carbon carriers individually, it can be stated that $\mathrm{C}_{\mathrm{AP}-\mathrm{L}}$ and $\mathrm{C}_{\mathrm{AP}-\mathrm{H}}$ indicated broad bands in the range $870-1340 \mathrm{~cm}^{-1}$, which can be assigned to the $\mathrm{N}-\mathrm{H}$ bonds and their out-ofplane deformation. The sharp band at $1392 \mathrm{~cm}^{-1}$ visible in the spectrum of the $\mathrm{C}_{\mathrm{AP}-\mathrm{L}}$ sample may belong to the $-\mathrm{CH}_{3}$ symmetrical bending vibrations and the $\mathrm{N}-\mathrm{CH}$ stretching vibrations [54]. There is no such sharp band in $\mathrm{C}_{\text {AP-H }}$ spectra. However, the broad band in the region of $1357-1615 \mathrm{~cm}^{-1}$ can be assigned to overlapping vibrations derived from either surface $-\mathrm{OH}$ groups or $\mathrm{C}=\mathrm{C}-\mathrm{H}, \mathrm{C}-\mathrm{N}$ - in heterocyclic rings, and carboxyl-carbonates structures [55]. A new band emerged in the spectra of $\mathrm{C}_{\mathrm{AP}-\mathrm{L}}+\mathrm{LOS}$ and $\mathrm{C}_{\mathrm{AP}-\mathrm{H}}+\mathrm{LOS}$ at 
$\sim 765 \mathrm{~cm}^{-1}$, which is a slightly shifted band from stretching vibrations of $\mathrm{C}-\mathrm{Cl}$ present in the losartan. The sharp bands at $\sim 1600 \mathrm{~cm}^{-1}$ ascribed to $\mathrm{C}=\mathrm{C}$ and $\mathrm{C}-\mathrm{H}$ from the aromatic ring but also at $\sim 1725 \mathrm{~cm}^{-1}$ typically assigned to the stretching vibrations from $\mathrm{C}=\mathrm{O}$ are observed in the spectra of pristine $\mathrm{C}_{\mathrm{SBA}-15}$ and $\mathrm{C}_{\mathrm{CH}-\mathrm{L}}$ samples. Non-modified and chitosanmodified materials revealed a wide band at $850-1320 \mathrm{~cm}^{-1}$ corresponding to the $\mathrm{N}-\mathrm{H}$ bonds similar to N-doped carbons. These materials are also rich in carboxylic, ester, etheric, and phenolic groups. Moreover, new bands appeared after API adsorption, most notably at $995 \mathrm{~cm}^{-1}, 1115 \mathrm{~cm}^{-1}$, and $1265 \mathrm{~cm}^{-1}$, which can be assigned to the stretching vibrations of $\mathrm{C}-\mathrm{O}, \mathrm{C}-\mathrm{N}$, and wagging vibrations of $\mathrm{C}-\mathrm{H}$ from losartan.

In conclusion, the FT-IR spectra of all functionalized mesoporous carbons after adsorption of losartan exhibit bands characteristic for the selected drug. However, it is worth noting that some bands are shifted or their intensity changes, which is the result of drug binding to the surface of the mesoporous carbon carriers.

Among all synthesized nanocarriers, pure ordered mesoporous carbon $\mathrm{C}_{\mathrm{SBA}-15}$ is characterized by the highest sorption capacity in relation to losartan $\left(161 \mathrm{mg} \mathrm{g}^{-1}\right)$, which can be attributed primarily to its most developed specific surface area and large pore volume (Figure 7). These results are similar to our previous reports comparing paracetamol adsorption on carbons obtained by hard and soft template approaches [18]. Due to the fact that losartan occurs in the anionic form at a $\mathrm{pH} 7$ and the carbon surface is negatively charged, electrostatic interactions cannot take place. Therefore, drug adsorption onto the surface of $\mathrm{C}_{\mathrm{SBA}-15}$ is mainly based on the formation of hydrogen bonds and $\pi-\pi$ interactions. In the case of chitosan-modified mesoporous carbons, the sorption capacity towards losartan decreases to $151 \mathrm{mg} \mathrm{g}^{-1}$ for $\mathrm{C}_{\mathrm{CH}-\mathrm{L}}$ and $112 \mathrm{mg} \mathrm{g}^{-1}$ for $\mathrm{C}_{\mathrm{CH}-\mathrm{H}}$ compared to $\mathrm{C}_{\mathrm{SBA}-15}$. It can be explained by the presence of a large number of acidic oxygen-containing moieties on the surface of these materials, which may partially repulse the functional groups of hydrophobic losartan molecules. Moreover, the modification with chitosan caused a deterioration of the textural parameters of the samples, which has been also reported for chitosan-coated silica particles a ibuprofen delivery [56]. Some of the entrances to the mesopores/micropores are blocked by chitosan functional groups, preventing the diffusion of losartan molecules into their interior. On the other hand, when analyzing carbons containing nitrogen in their structure, it should be emphasized that $\mathrm{C}_{\mathrm{AP}-\mathrm{L}}\left(97 \mathrm{mg} \mathrm{g}^{-1}\right)$ exhibits a better sorption capacity than $\mathrm{C}_{\mathrm{AP}-\mathrm{H}}\left(59 \mathrm{mg} \mathrm{g}^{-1}\right)$, which indicates its greater affinity for the studied drug (Figure 7). This is primarily due to the presence of basic functional groups that can electrostatically interact with the negatively charged functional groups of the drug. However, other specific/chemical interactions must be also taken into account when analyzing the mechanism of the losartan adsorption process, e.g., hydrogen bond formation, $\pi-\pi$ interactions.

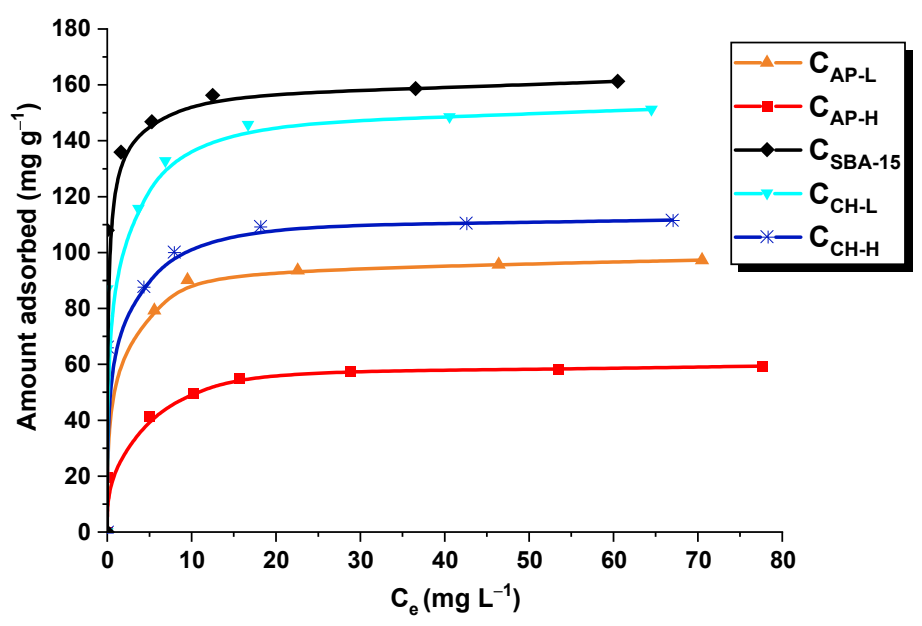

Figure 7. Adsorption isotherms of losartan potassium on the surface of $\mathrm{C}_{\mathrm{AP}-\mathrm{L}}, \mathrm{C}_{\mathrm{AP}-\mathrm{H}}, \mathrm{C}_{\mathrm{SBA}-15}, \mathrm{C}_{\mathrm{CH}-\mathrm{L}}$, and $\mathrm{C}_{\mathrm{CH}-\mathrm{H}}$ carriers. 
The experimental data of losartan adsorption on the surface of $\mathrm{C}_{\mathrm{SBA}-15}, \mathrm{C}_{\mathrm{CH}-\mathrm{H}}, \mathrm{C}_{\mathrm{CH}-\mathrm{L}}$, $\mathrm{C}_{\mathrm{AP}-\mathrm{H}}$, and $\mathrm{C}_{\mathrm{AP}-\mathrm{L}}$ nanocarriers at equilibrium were fitted to the linear form of Langmuir and Freundlich isotherm models (Figure 8). The adsorption parameters estimated based on these two models are listed in Table 3 . Evaluating the $R^{2}$ values for the systems studied, it was noticed that the Langmuir model described better drug adsorption on the carbon materials than the Freundlich ones. The $\mathrm{K}_{\mathrm{L}}$ parameter in the Langmuir equation is related to the drug affinity to adsorbents. Comparing the obtained values of this parameter, a greater affinity of losartan to pristine and chitosan-modified ordered mesoporous carbons $\mathrm{C}_{\mathrm{SBA}-15}$ was observed.

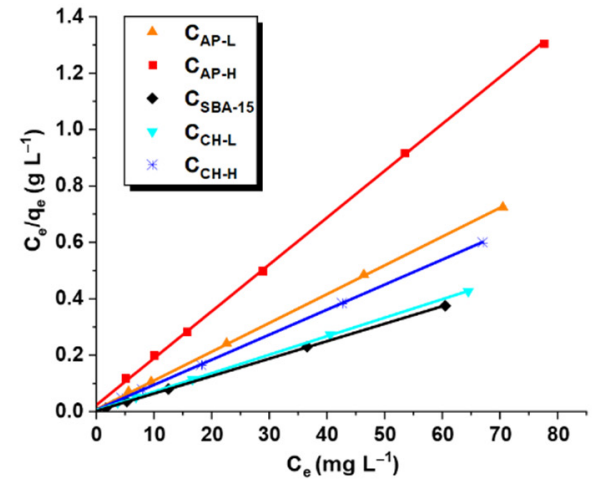

(A)

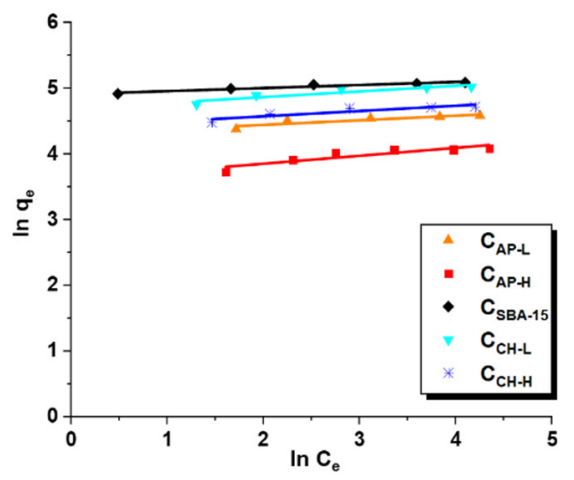

(B)

Figure 8. The fitting of experimental data of adsorption of losartan potassium on the surface of $\mathrm{C}_{\mathrm{AP}-\mathrm{L}}$, $\mathrm{C}_{\mathrm{AP}-\mathrm{H}}, \mathrm{C}_{\mathrm{SBA}-15}, \mathrm{C}_{\mathrm{CH}-\mathrm{L}}$, and $\mathrm{C}_{\mathrm{CH}-\mathrm{H}}$ carriers to the Langmuir (A) and Freundlich (B) models.

Table 3. The parameters of Langmuir and Freundlich isotherm models fitted to equilibrium data of losartan adsorption on the surface of functionalized mesoporous carbon materials.

\begin{tabular}{|c|c|c|c|c|c|c|}
\hline \multirow{2}{*}{ Material } & \multicolumn{3}{|c|}{ Langmuir } & \multicolumn{3}{|c|}{ Freundlich } \\
\hline & $q_{m}(m g / g)$ & $\mathrm{K}_{\mathrm{L}}(\mathrm{L} / \mathrm{mg})$ & $\mathbf{R}^{2}$ & $K_{F}\left(m g / g(L / m g)^{1 / n}\right)$ & $1 / n$ & $\mathbf{R}^{2}$ \\
\hline $\mathrm{C}_{\mathrm{AP}-\mathrm{L}}$ & 98 & 1.268 & 0.999 & 74 & 0.070 & 0.814 \\
\hline $\mathrm{C}_{\mathrm{AP}-\mathrm{H}}$ & 60 & 0.722 & 0.999 & 37 & 0.121 & 0.826 \\
\hline $\mathrm{C}_{\mathrm{SBA}-15}$ & 162 & 2.948 & 0.999 & 135 & 0.046 & 0.933 \\
\hline $\mathrm{C}_{\mathrm{CH}-\mathrm{L}}$ & 152 & 1.331 & 0.999 & 109 & 0.086 & 0.855 \\
\hline $\mathrm{C}_{\mathrm{CH}-\mathrm{H}}$ & 112 & 1.450 & 0.999 & 82 & 0.081 & 0.820 \\
\hline
\end{tabular}

The losartan release results in the acceptor simulating gastric fluid $\left(0.1 \mathrm{~mol} \mathrm{~L}^{-1} \mathrm{HCl}\right)$ are presented in Figure 9. All carbon materials indicated the ability to release the selected drug. The percentage of losartan liberated from the nanoporous carriers ranges from $\sim 16 \%$ to $\sim 90 \%$ depending on the carbon platform applied. Soft-templated carbons $\left(\mathrm{C}_{\mathrm{AP}-\mathrm{L}}, \mathrm{C}_{\mathrm{AP}-\mathrm{H}}\right)$ stand out with the rapid release of losartan potassium. $\mathrm{C}_{\mathrm{AP}-\mathrm{L}}$ sample liberated $84 \%$ of adsorbed API within $60 \mathrm{~min}$, with less intense release in the following hours-up to $90.46 \%$. On the other hand, in the case of the second nitrogen-doped carrier $\left(\mathrm{C}_{\mathrm{AP}-\mathrm{H}}\right)$, the drug concentration $(52.35 \%)$ in the receptor fluid stabilizes after $30 \mathrm{~min}$ of the process. The burst of losartan from these carriers signifies that it was adsorbed on the external surface rather than in the pores, due to their relatively low porosity. Moreover, at $\mathrm{pH} 1.2$ functional groups of carbons and losartan itself (due to the acidic tetrazole ring) are protonated. Hence, electrostatic repulsion could occur leading to increased drug liberation [57-59]. The lack of $\sim 48 \%$ of losartan discharge from $\mathrm{C}_{\mathrm{AP}-\mathrm{H}}$ proves its greater affinity in acidic media to carbon with less amount of surface functional groups. Additionally, despite the comparable surface area of $\mathrm{C}_{\mathrm{AP}-\mathrm{L}}$ and $\mathrm{C}_{\mathrm{AP}-\mathrm{H}}$, the second material has a lower average pore diameter and pore volumes, which intensifies the interaction between the pore walls and losartan ultimately leading to lowered total drug release. 


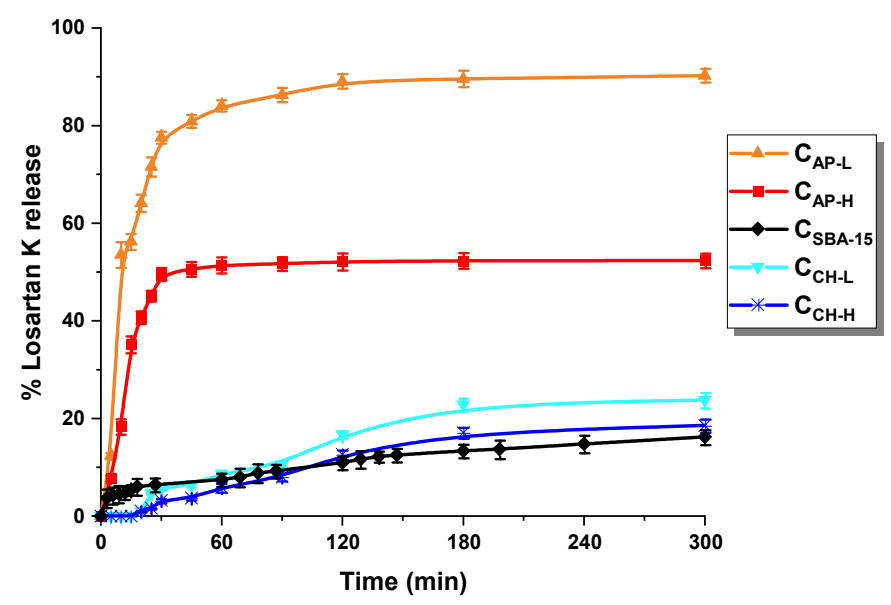

Figure 9. Release profiles of losartan potassium from carbon carriers: $\mathrm{C}_{\mathrm{AP}-\mathrm{L}}, \mathrm{C}_{\mathrm{AP}-\mathrm{H}}, \mathrm{C}_{\mathrm{SBA}-15}, \mathrm{C}_{\mathrm{CH}-\mathrm{L}}$, and $\mathrm{C}_{\mathrm{CH}-\mathrm{H}}$ in acidic medium $\left(\mathrm{HCl} 0.1 \mathrm{~mol} \mathrm{~L}^{-1}\right)$.

The mesoporous carbons obtained by the hard-templating method exhibited the contrary release behavior. The pristine sample $\mathrm{C}_{\mathrm{SBA}-15}$ liberated the least API $(16.22 \%)$, which is dictated by the most developed porous structure. Hence, losartan trapped in carbon pores diffused slowly and in small amounts. The modification with chitosan led to slightly increased drug desorption in a more controlled manner. The functionalized materials $\mathrm{C}_{\mathrm{CH}-\mathrm{L}}$ and $\mathrm{C}_{\mathrm{CH}-\mathrm{H}}$ released $23.76 \%$ and $18.56 \%$, respectively. The increased percentage of losartan release is due to decreased porosity of the carriers and partial drug adsorption on their external surfaces. Moreover, more oxygen functional groups prompt an increase in the efficiency of the liberation of adsorbed losartan. By taking an overall look at losartan release from soft- and hard-templated carbons, the latter appear to differ less. $\mathrm{C}_{\mathrm{SBA}-15}$ and chitosan-modified carbon textural parameters are unalike when one considers $\mathrm{S}_{\mathrm{BET}}$ and pore volumes, hence smaller differences in liberation must relate to disparate phenomena. In the case of non-modified carbon, LOS is mostly trapped within the carbon pore network; high affinity between adsorbent and adsorbate result in slow API liberation. However, where it comes to the modified materials, due to the modifier-induced decrease in specific surface area, the high affinity of LOS occurs due to the chitosan itself. Song et al. [60] reported a chitosan-modified carbon for pesticide (emamectin benzoate) delivery, which sustained the escape of active ingredient due to the metastable combination of the outer layer of the adsorbate. The strong interaction between chitosan and drug consequently results in similar slow desorption of the LOS; however, it opens the pathway to regulate release behavior. Nonetheless, the presence of varied results suggests that by using chitosan as a modifier with different molecular weights the total drug release can be modulated.

The in vitro losartan release data were evaluated kinetically using various mathematical models presented in Table 4. It was found that drug liberation from N-doped carbons fits the best to the first-order model: $\mathrm{R}^{2}=0.932$ and 0.974 for $\mathrm{C}_{\mathrm{AP}-\mathrm{L}}$ and $\mathrm{C}_{\mathrm{AP}-\mathrm{H}}$, respectively. Therefore, it can be stated that the release is dependent on the drug concentration, rather than on the carrier. This suggests that if more API would be adsorbed onto the carbon vehicle, the faster release would occur. The losartan liberation data for $\mathrm{C}_{\mathrm{SBA}-15}$ and $\mathrm{C}_{\mathrm{CH}-\mathrm{H}}$ exhibit the highest correlation coefficients $(0.988 ; 0.963)$ when the Higuchi model is applied. This model attests to a controlled manner of release and indicates that the diffusivity of the drug is constant. Additionally, it confirms that the initial losartan concentration in the system is higher than the carrier solubility in the acceptor medium. The last sample $\left(\mathrm{C}_{\mathrm{CH}-\mathrm{L}}\right)$ showed the highest and most similar values of the correlation coefficient for two models, the zero-order (0.971) and the Hixson-Crowell (0.970) models. The first model indicates the sustained drug liberation from the vehicle, whilst the second model signifies the dependence between carrier surface area and API dissolution [61]. 
Table 4. Parameters of kinetic release models suggesting the mechanism of diclofenac liberation from carbon vehicles.

\begin{tabular}{|c|c|c|c|c|c|c|c|c|c|c|c|}
\hline \multirow[b]{2}{*}{ Material } & \multicolumn{2}{|c|}{ Zero-Order } & \multicolumn{2}{|c|}{ First-Order } & \multicolumn{2}{|c|}{ Higuchi } & \multicolumn{2}{|c|}{ Hixson-Crowell } & \multicolumn{3}{|c|}{ Korsmeyer-Peppas } \\
\hline & $\begin{array}{c}\mathbf{k}_{0} \\
{\left[\mathbf{h}^{-1}\right]}\end{array}$ & $\mathbf{R}^{2}$ & $\begin{array}{c}\mathbf{k}_{\mathbf{1}} \\
{\left[\mathbf{h}^{-1}\right]}\end{array}$ & $\mathbf{R}^{2}$ & $\begin{array}{c}\mathbf{k}_{\mathbf{H}} \\
{\left[h^{-1 / 2}\right]}\end{array}$ & $\mathbf{R}^{2}$ & $\underset{\left[h^{-1 / 3}\right]}{k_{H C}}$ & $\mathbf{R}^{2}$ & $\begin{array}{c}\mathbf{k}_{\mathbf{K P}} \\
{\left[\mathbf{h}^{-\mathbf{n}}\right]}\end{array}$ & $\mathbf{n}$ & $\mathbf{R}^{2}$ \\
\hline $\mathrm{C}_{\mathrm{AP}-\mathrm{L}}$ & 1.797 & 0.762 & 0.036 & 0.932 & 12.455 & 0.901 & 0.038 & 0.871 & 7.123 & 0.683 & 0.758 \\
\hline $\mathrm{C}_{\mathrm{AP}-\mathrm{H}}$ & 0.824 & 0.824 & 0.024 & 0.974 & 10.316 & 0.882 & 0.015 & 0.696 & 2.335 & 0.895 & 0.899 \\
\hline $\mathrm{C}_{\text {SBA-15 }}$ & 0.047 & 0.903 & 0.001 & 0.916 & 0.821 & 0.988 & 0.001 & 0.912 & 1.901 & 0.369 & 0.969 \\
\hline $\mathrm{C}_{\mathrm{CH}-\mathrm{L}}$ & 0.133 & 0.971 & 0.001 & 0.891 & 2.092 & 0.963 & 0.002 & 0.970 & 0.935 & 0.112 & 0.761 \\
\hline $\mathrm{C}_{\mathrm{CH}-\mathrm{H}}$ & 0.073 & 0.912 & 0.001 & 0.920 & 1.446 & 0.963 & 0.001 & 0.907 & 0.063 & 1.060 & 0.940 \\
\hline
\end{tabular}

Losartan potassium belongs to class III of drugs with low solubility and high permeability according to the biopharmaceutics classification system (BCS) [62]. Its permeability coefficient was $12.14 \times 10^{-7} \mathrm{~cm} \mathrm{~s}^{-1}$, which corresponds to literature data for well permeable compounds $\left(>10.00 \times 10^{-7} \mathrm{~cm} \mathrm{~s}^{-1}\right)$. The permeability of losartan introduced onto the $\mathrm{N}$-doped and chitosan-modified carbons is depicted in Figure 10. API liberated from the carriers indicated reduced permeability in comparison to the pure losartan. The smallest alteration of Papp value was caused by the carrier $\mathrm{C}_{\mathrm{AP}-\mathrm{L}}\left(9.94 \times 10^{-7} \mathrm{~cm} \mathrm{~s}^{-1}\right)$. It correlates with the most efficient release of drug from this carrier. $\mathrm{C}_{\mathrm{AP}-\mathrm{H}}$ exhibited $4.44 \times 10^{-7} \mathrm{~cm} \mathrm{~s}^{-1}$ permeability. The losartan delivery systems based on chitosan-modified carbon carriers have the lowest permeability of $1.14 \times 10^{-7} \mathrm{~cm} \mathrm{~s}^{-1}\left(\mathrm{C}_{\mathrm{CH}-\mathrm{L}}\right)$, and $1.92 \times 10^{-7} \mathrm{~cm} \mathrm{~s}^{-1}$ $\left(\mathrm{C}_{\mathrm{CH}-\mathrm{H}}\right)$.

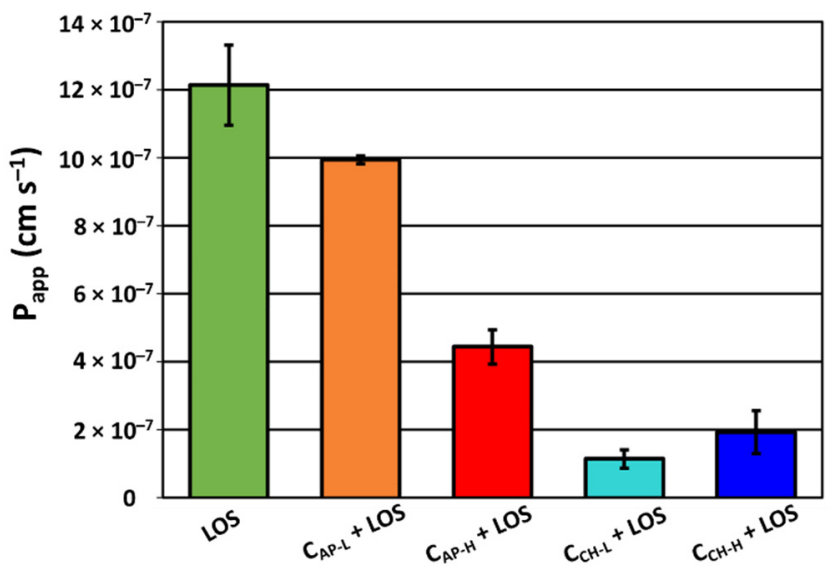

Figure 10. Gastrointestinal mean permeability of intrinsic losartan potassium and after liberation from functionalized ordered mesoporous carbons.

\section{Conclusions}

In this article, advanced losartan potassium delivery systems based on functionalized ordered mesoporous carbon materials of different morphology were presented. To obtain carbon materials with desired physicochemical properties, two synthetic approaches were applied. The first, the soft-templating method with Pluronic F127, was modified by adding nitrogen sources-3-aminophenol and L-arginine. Thanks to this approach, it was possible to fabricate nitrogen-doped mesoporous carbons characterized by the presence of basic functional groups and polyhedral or corrugated particles. The second group of carbonaceous carriers was synthesized by the hard-templating method, relying on the SBA15 silica matrix, followed by chitosan biopolymer functionalization. These materials exhibit a high amount of acidic surface oxygen-containing moieties and worm-like morphology. The modification of mesoporous carbons brought about a reduction in the ordering of their hexagonal structure, and, subsequently, the textural parameters deteriorated compared to the pristine sample. The sorption capacities of carbon vehicles towards losartan potassium are dependent on their porosity and morphology, as well as amount and nature of surface 
functional groups. Materials synthesized by the hard-templating method and modified with chitosan adsorb more API than nitrogen-enriched carbons. This is due to their higher specific surface area and pore volumes. Moreover, a high concentration of surface functional groups favors the intensification of host-guest interactions. Among applied adsorption isotherm models, the Langmuir one shows the best fit with the experimental data. The monolayer sorption capacities of mesoporous carbon samples are in the range 59-161 $\mathrm{mg} \mathrm{g}^{-1}$. It has been shown that the choice of nanocarrier synthesis method, its parameters, and its modification have a significant impact on the kinetics of losartan potassium release, which can be modulated depending on the needs. The use of nitrogendoped carbons as a delivery platform resulted in the faster and more effective liberation of the drug. On the other hand, in the case of chitosan-functionalized nanocarriers, the release of losartan potassium was gradual and occurred in a controlled manner. However, within $5 \mathrm{~h}$ of the process, the lower drug concentration in the acceptor fluid was determined.

Author Contributions: A.E.-Investigation, Visualization, and Writing-Original Draft Preparation; A.S.-K.-Investigation; D.L.-Investigation; J.C.-P.-Conceptualization, Writing-Review and Editing; J.G.-Conceptualization, Investigation, Supervision, Writing-Original Draft Preparation, Writing-Review and Editing, and Visualization. All authors have read and agreed to the published version of the manuscript.

Funding: This research was supported by the National Science Centre, Poland (project SONATA-12 no: 2016/23/D/NZ7/01347).

Institutional Review Board Statement: Not applicable.

Informed Consent Statement: Not applicable.

Data Availability Statement: Data available in a publicly accessible repository.

Conflicts of Interest: There are no conflict to declare.

\section{References}

1. Ripley, E.; Hirsch, A. Fifteen years of losartan: What have we learned about losartan that can benefit chronic kidney disease patients? Int. J. Nephrol. Renovasc. Dis. 2010, 3, 93-98. [CrossRef] [PubMed]

2. Napoleone, E.; Cutrone, A.; Cugino, D.; Amore, C.; Di Santo, A.; Iacoviello, L.; de Gaetano, G.; Donati, M.B.; Lorenzet, R. Inhibition of the renin-angiotensin system downregulates tissue factor and vascular endothelial growth factor in human breast carcinoma cells. Thromb. Res. 2012, 129, 736-742. [CrossRef]

3. Barati, F.; Pouresmaieli, M.; Ekrami, E.; Asghari, S.; Ziarani, F.R.; Mamoudifard, M. Potential Drugs and Remedies for the Treatment of COVID-19: A Critical Review. Biol. Proced. Online 2020, 22, 15. [CrossRef]

4. Drews, H.J.; Klein, R.; Lourhmati, A.; Buadze, M.; Schaeffeler, E.; Lang, T.; Seferyan, T.; Hanson, L.R.; Frey, W.H.; de Vries, T.C.G.M.; et al. Losartan improves memory, neurogenesis and cell motility in transgenic alzheimer's mice. Pharmaceuticals 2021, 14, 166. [CrossRef]

5. Danielyan, L.; Klein, R.; Hanson, L.R.; Buadze, M.; Schwab, M.; Gleiter, C.H.; Frey, W.H. Protective effects of intranasal losartan in the APP/PS1 transgenic mouse model of Alzheimer disease. Rejuvenation Res. 2010, 13, 195-201. [CrossRef] [PubMed]

6. Shinde, A.K.J.; Patil, N.S.; Jadhav, T.S.; More, H.N. Design and development of floating pulsatile drug delivery of losartan potassium. Int. J. Appl. Pharm. 2020, 12, 218-227. [CrossRef]

7. Chen, R.N.; Ho, H.O.; Yu, C.Y.; Sheu, M.T. Development of swelling/floating gastroretentive drug delivery system based on a combination of hydroxyethyl cellulose and sodium carboxymethyl cellulose for Losartan and its clinical relevance in healthy volunteers with CYP2C9 polymorphism. Eur. J. Pharm. Sci. 2010, 39, 82-89. [CrossRef] [PubMed]

8. Bajpai, M.; Singh, D.C.P.; Bhattacharya, A.; Singh, A. Design and in vitro evaluation of compression-coated pulsatile release tablets of losartan potassium. Indian J. Pharm. Sci. 2012, 74, 101-106. [CrossRef] [PubMed]

9. Kommana, N.; Bharti, K.; Surekha, D.B.; Thokala, S.; Mishra, B. Development, optimization and evaluation of losartan potassium loaded Self Emulsifying Drug Delivery System. J. Drug Deliv. Sci. Technol. 2020, 60, 102026. [CrossRef]

10. Vashisth, I.; Ahad, A.; Aqil, M.; Agarwal, S.P. Investigating the potential of essential oils as penetration enhancer for transdermal losartan delivery: Effectiveness and mechanism of action. Asian J. Pharm. Sci. 2014, 9, 260-267. [CrossRef]

11. Almazan, E.A.; Castañeda, P.S.; Torres, R.D.; Escobar-Chavez, J.J. Design and evaluation of Losartan transdermal patch by using solid microneedles as a physical permeation enhancer. Iran. J. Pharm. Res. 2020, 19, 138-152. [CrossRef] [PubMed]

12. Farjadian, F.; Roointan, A.; Mohammadi-Samani, S.; Hosseini, M. Mesoporous silica nanoparticles: Synthesis, pharmaceutical applications, biodistribution, and biosafety assessment. Chem. Eng. J. 2019, 359, 684-705. [CrossRef] 
13. Liu, Z.; Robinson, J.T.; Tabakman, S.M.; Yang, K.; Dai, H. Carbon materials for drug delivery \& cancer therapy. Mater. Today 2011, 14, 316-323. [CrossRef]

14. Farjadian, F.; Ghasemi, S.; Heidari, R.; Mohammadi-Samani, S. In vitro and in vivo assessment of EDTA-modified silica nanospheres with supreme capacity of iron capture as a novel antidote agent. Nanomed. Nanotechnol. Biol. Med. 2017, 13, 745-753. [CrossRef]

15. Taqanaki, E.R.; Heidari, R.; Monfared, M.; Tayebi, L.; Azadi, A.; Farjadian, F. EDTA-modified mesoporous silica as supra adsorbent of copper ions with novel approach as an antidote agent in copper toxicity. Int. J. Nanomed. 2019, 14, 7781-7792. [CrossRef]

16. De Andrade, J.R.; Da Silva, M.G.C.; Gimenes, M.L.; Vieira, M.G.A. Performance of organoclay in adsorptive uptake of antihypertensive losartan potassium: A comparative batch study using micro-grain activated carbon. J. Environ. Chem. Eng. 2020, $8,103562$. [CrossRef]

17. De Andrade, J.R.; Vieira, M.G.A.; da Silva, M.G.C.; Wang, S. Oxidative degradation of pharmaceutical losartan potassium with N-doped hierarchical porous carbon and peroxymonosulfate. Chem. Eng. J. 2020, 382, 122971. [CrossRef]

18. Goscianska, J.; Ejsmont, A.; Olejnik, A.; Ludowicz, D.; Stasiłowicz, A.; Cielecka-Piontek, J. Design of paracetamol delivery systems based on functionalized ordered mesoporous carbons. Materials 2020, 13, 4151. [CrossRef]

19. Goscianska, J.; Ejsmont, A.; Kubiak, A.; Ludowicz, D.; Stasiłowicz, A.; Cielecka-Piontek, J. Amine-grafted mesoporous carbons as benzocaine-delivery platforms. Materials 2021, 14, 2188. [CrossRef] [PubMed]

20. Goscianska, J.; Olejnik, A.; Ejsmont, A.; Galarda, A.; Wuttke, S. Overcoming the paracetamol dose challenge with wrinkled mesoporous carbon spheres. J. Colloid Interface Sci. 2021, 586, 673-682. [CrossRef]

21. Zhao, Q.; Lin, Y.; Han, N.; Li, X.; Geng, H.; Wang, X.; Cui, Y.; Wang, S. Mesoporous carbon nanomaterials in drug delivery and biomedical application. Drug Deliv. 2017, 24, 94-107. [CrossRef] [PubMed]

22. Rajakumar, G.; Zhang, X.H.; Gomathi, T.; Wang, S.F.; Ansari, M.A.; Mydhili, G.; Nirmala, G.; Alzohairy, M.A.; Chung, I.M Current use of carbon-based materials for biomedical applications-A prospective and review. Processes 2020, 8, 355. [CrossRef]

23. Chakrabarti, M.; Kiseleva, R.; Vertegel, A.; Ray, S.K. Carbon nanomaterials for drug delivery and cancer therapy. J. Nanosci. Nanotechnol. 2015, 15, 5501-5511. [CrossRef] [PubMed]

24. Jun, S.; Joo, S.H.; Ryoo, R.; Kruk, M.; Jaroniec, M.; Liu, Z.; Ohsuna, T.; Terasaki, O. Synthesis of new, nanoporous carbon with hexagonally ordered mesostructure. J. Am. Chem. Soc. 2000, 122, 10712-10713. [CrossRef]

25. Malgras, V.; Tang, J.; Wang, J.; Kim, J.; Torad, N.L.; Dutta, S.; Ariga, K.; Hossain, M.S.A.; Yamauchi, Y.; Wu, K.C.W. Fabrication of Nanoporous Carbon Materials with Hard- and Soft-Templating Approaches: A Review. J. Nanosci. Nanotechnol. 2019, 19, 3673-3685. [CrossRef] [PubMed]

26. Ma, X.; Yuan, H.; Hu, M. A simple method for synthesis of ordered mesoporous carbon. Diam. Relat. Mater. 2019, 98, 107480. [CrossRef]

27. Ramasamy, E.; Jo, C.; Anthonysamy, A.; Jeong, I.; Kim, J.K.; Lee, J. Soft-template simple synthesis of ordered mesoporous titanium nitride-carbon nanocomposite for high performance dye-sensitized solar cell counter electrodes. Chem. Mater. 2012, 24, 1575-1582. [CrossRef]

28. Xiao, P.W.; Zhao, L.; Sui, Z.Y.; Xu, M.Y.; Han, B.H. Direct synthesis of ordered mesoporous hydrothermal carbon materials via a modified soft-templating method. Microporous Mesoporous Mater. 2017, 253, 215-222. [CrossRef]

29. Meng, Y.; Wang, S.; Li, C.; Qian, M.; Yan, X.; Yao, S.; Peng, X.; Wang, Y.; Huang, R. Photothermal combined gene therapy achieved by polyethyleneimine-grafted oxidized mesoporous carbon nanospheres. Biomaterials 2016, 100, 134-142. [CrossRef] [PubMed]

30. Gencoglu, M.F.; Spurri, A.; Franko, M.; Chen, J.; Hensley, D.K.; Heldt, C.L.; Saha, D. Biocompatibility of soft-templated mesoporous carbons. ACS Appl. Mater. Interfaces 2014, 6, 15068-15077. [CrossRef] [PubMed]

31. Kim, T.W.; Chung, P.W.; Slowing, I.I.; Tsunoda, M.; Yeung, E.S.; Lin, V.S.Y. Structurally ordered mesoporous carbon nanoparticles as transmembrane delivery vehicle in human cancer cells. Nano Lett. 2008, 8, 3724-3727. [CrossRef]

32. Li, C.; Meng, Y.; Wang, S.; Qian, M.; Wang, J.; Lu, W.; Huang, R. Mesoporous Carbon Nanospheres Featured Fluorescent Aptasensor for Multiple Diagnosis of Cancer In Vitro and In Vivo. ACS Nano 2015, 9, 12096-12103. [CrossRef]

33. Omidi, F.; Dehghani, F.; Jamaleddin Shahtaheri, S. N-doped mesoporous carbon as a new sorbent for ultrasonic-assisted dispersive micro-solid-phase extraction of 1-naphthol and 2-naphthol, the biomarkers of exposure to naphthalene, from urine samples. J. Chromatogr. B Anal. Technol. Biomed. Life Sci. 2020, 1160, 122353. [CrossRef]

34. Wang, J.; Hu, Z.; Xu, J.; Zhao, Y. Therapeutic applications of low-toxicity spherical nanocarbon materials. NPG Asia Mater. 2014, 6, e84. [CrossRef]

35. Chen, Y.; Shi, J. Mesoporous carbon biomaterials. Sci. China Mater. 2015, 58, 241-257. [CrossRef]

36. Rahman, M.M.; Ara, M.G.; Alim, M.A.; Uddin, M.S.; Najda, A.; Albadrani, G.M.; Sayed, A.A.; Mousa, S.A.; Abdel-Daim, M.M. Mesoporous carbon: A versatile material for scientific applications. Int. J. Mol. Sci. 2021, 22, 4498. [CrossRef]

37. Huang, X.; Wu, S.; Du, X. Gated mesoporous carbon nanoparticles as drug delivery system for stimuli-responsive controlled release. Carbon N. Y. 2016, 101, 135-142. [CrossRef]

38. Panda, S.; Bhol, C.S.; Bhutia, S.K.; Mohapatra, S. PEG-PEI-modified gated N-doped mesoporous carbon nanospheres for pH/NIR light-triggered drug release and cancer phototherapy. J. Mater. Chem. B 2021, 9, 3666-3676. [CrossRef]

39. Bernkop-Schnürch, A.; Dünnhaupt, S. Chitosan-based drug delivery systems. Eur. J. Pharm. Biopharm. 2012, 81, 463-469. [CrossRef] 
40. Liu, D.; Zeng, C.; Qu, D.; Tang, H.; Li, Y.; Su, B.L.; Qu, D. Highly efficient synthesis of ordered nitrogen-doped mesoporous carbons with tunable properties and its application in high performance supercapacitors. J. Power Sources 2016, 321, 143-154. [CrossRef]

41. Langmuir, I. The adsorption of gases on plane surfaces of glass, mica and platinum. J. Am. Chem. Soc. 1918, 40, 1361-1403. [CrossRef]

42. Fruendlich, H.M.F. Over the adsorption in solution. J. Phys. Chem. 1906, 57, 385-471.

43. Dash, S.; Murthy, P.N.; Nath, L.; Chowdhury, P. Kinetic modeling on drug release from controlled drug delivery systems. Acta Pol. Pharm. Drug Res. 2010, 67, 217-223.

44. Cao, C.; Wu, X.; Zheng, Y.; Zhang, D.; Chen, J.; Chen, Y. Ordered mesoporous carbon with chitosan for disinfection of water via capacitive deionization. Nanomaterials 2020, 10, 489. [CrossRef]

45. Esparza, J.M.; Ojeda, M.L.; Campero, A.; Domínguez, A.; Kornhauser, I.; Rojas, F.; Vidales, A.M.; López, R.H.; Zgrablich, G. N2 sorption scanning behavior of SBA-15 porous substrates. Colloids Surf. A Physicochem. Eng. Asp. 2004, 241, 35-45. [CrossRef]

46. Liu, S.; Zuo, P.; Wang, Y.; Li, X.; Zhang, W.; Xu, S.; Huo, P.; Li, Z. Nitrogen-doped ordered mesoporous carbon microspheres made from $\mathrm{m}$-aminophenol-formaldehyde resin as promising electrode materials for supercapacitors. Microporous Mesoporous Mater. 2018, 259, 54-59. [CrossRef]

47. Chandrasekar, G.; Son, W.J.; Ahn, W.S. Synthesis of mesoporous materials SBA-15 and CMK-3 from fly ash and their application for CO2 adsorption. J. Porous Mater. 2009, 16, 545-551. [CrossRef]

48. Boehm, H.P. Some aspects of the surface chemistry of carbon blacks and other carbons. Carbon N. Y. 1994, 32, 759-769. [CrossRef]

49. Santiago, M.; Stüber, F.; Fortuny, A.; Fabregat, A.; Font, J. Modified activated carbons for catalytic wet air oxidation of phenol. Carbon N. Y. 2005, 43, 2134-2145. [CrossRef]

50. Domingo-García, M.; López Garzón, F.J.; Pérez-Mendoza, M.J. On the characterization of chemical surface groups of carbon materials. J. Colloid Interface Sci. 2002, 248, 116-122. [CrossRef]

51. Amer, M.A.; Essa, E.A.; Donia, A.A.; El Maghraby, G.M. Development and evaluation of liquid oral controlled release systems for Losartan potassium. J. Appl. Pharm. Sci. 2019, 9, 86-93. [CrossRef]

52. Goscianska, J.; Galarda, A.; Ejsmont, A.; Wuttke, S. Identification of the Physicochemical Factors Involved in the Dye Separation via Methionine-Functionalized Mesoporous Carbons. Adv. Sustain. Syst. 2021, 5, 2100013. [CrossRef]

53. Queiroz, M.F.; Melo, K.R.T.; Sabry, D.A.; Sassaki, G.L.; Rocha, H.A.O. Does the use of chitosan contribute to oxalate kidney stone formation? Mar. Drugs 2015, 13, 141-158. [CrossRef]

54. Misra, A.; Tyagi, P.K.; Singh, M.K.; Misra, D.S. FTIR studies of nitrogen doped carbon nanotubes. Diam. Relat. Mater. 2006, 15, 385-388. [CrossRef]

55. Biniak, S.; Szymański, G.; Siedlewski, J.; Światkoski, A. The characterization of activated carbons with oxygen and nitrogen surface groups. Carbon N. Y. 1997, 35, 1799-1810. [CrossRef]

56. Popat, A.; Liu, J.; Lu, G.Q.; Qiao, S.Z. A pH-responsive drug delivery system based on chitosan coated mesoporous silica nanoparticles. J. Mater. Chem. 2012, 22, 11173-11178. [CrossRef]

57. De Oliveira Rossini, P.; Felix, F.S.; Angnes, L. A simple and precise conductometric method for the determination of losartan in pharmaceutical products. Cent. Eur. J. Chem. 2012, 10, 1842-1849. [CrossRef]

58. Behera, S.K.; Oh, S.Y.; Park, H.S. Sorptive removal of ibuprofen from water using selected soil minerals and activated carbon. Int J. Environ. Sci. Technol. 2012, 9, 85-94. [CrossRef]

59. Caldera-Villalobos, M.; Peláez-Cid, A.A.; Martins-Alho, M.A.; Herrera-González, A.M. Removal of textile dyes in wastewater using polyelectrolytes containing tetrazole groups. Korean J. Chem. Eng. 2018, 35, 2394-2402. [CrossRef]

60. Song, S.; Wang, Y.; Xie, J.; Sun, B.; Zhou, N.; Shen, H.; Shen, J. Carboxymethyl Chitosan Modified Carbon Nanoparticle for Controlled Emamectin Benzoate Delivery: Improved Solubility, pH-Responsive Release, and Sustainable Pest Control. ACS Appl. Mater. Interfaces 2019, 11, 34258-34267. [CrossRef]

61. Baishya, H. Application of Mathematical Models in Drug Release Kinetics of Carbidopa and Levodopa ER Tablets. J. Dev. Drugs 2017, 6, 1000171. [CrossRef]

62. Viswanath, V.; Chandrasekhar, U.; Rao, B.N.; Prakash, K.G. Development and evaluation of sustained release matrix tablets of losartan potassium. Int. J. Appl. Pharm. Sci. Res. 2016, 1, 127-132. [CrossRef] 